by Jun Niu ${ }^{1,2 *}$, Wen-Hui Huang ${ }^{3}$, and Fei Liang ${ }^{3}$

\title{
Geochemical characteristics and genesis of Lower Ordovician dolomite in the southwest Tarim Basin, Northwest China
}

\author{
${ }^{1}$ Faculty of Petroleum,China University of Petroleum-Beijing,Karamay Campus, Karamay 834000, Xinjiang, China; *Corresponding author, \\ E-amil:1f9318@outlook.com \\ ${ }^{2}$ State Key Laboratory of Petroleum Resources and Prospecting; China University of Petroleum (Beijing), Beijing 100249, China \\ ${ }^{3}$ School of Energy Resource, China University of Geosciences, Beijing 100083, China
}

(Received: August 1, 2018; Revised accepted: February 11, 2019)

https://doi.org/10.18814/epiiugs/2019/019004

The Ordovician dolomite stratum in the southwest Tarim Basin is rich in oil and gas, but the reservoir is characterized by low porosity, low permeability, and strong heterogeneity. Using drill core samples, this study examined the petrologic features, geochemical characteristics, homogenization temperatures of inclusions, and the genesis of dolomite in the Lower Ordovician was discussed. Results showed that in the Penglaiba and Yingshan Formation dolomite content decreased from bottom to top. The predominant type of dolomite was silt to fine, with middlecoarse and saddle dolomite distributed along fractures and the bottom of the Penglaiba Formation. $\delta^{13} C$ values ranged between $-2.6 \%$ and $0.7 \%$, $\delta^{18} \mathrm{O}$ fluctuated between $-3.5 \%$ and $-9.4 \%$ o ${ }^{87} \mathrm{Sr}{ }^{86} \mathrm{Sr}$ values were $0.7087-0.7104$, and part of the value exceeded largest value of Ordovician. In addition, inclusion data could be divided into four groups, indicated there were at least three stage of diagenetic fluid $\left(100-110^{\circ} \mathrm{C} ; 120-150^{\circ} \mathrm{C} ; 160-170^{\circ} \mathrm{C}\right)$ and one hydrothermal fluid $\left(180-210^{\circ} \mathrm{C}\right)$ activity. The genesis of dolomite in the study area was mainly contemporaneous - penecontemporaneous dolomitization, with burial and hydrothermal dolomitization around fractures and fault zones.

\section{Introduction}

Dolomite is widely distributed throughout geological history and is an important oil and gas reservoir in sedimentary basins ( $\mathrm{Wu}$ et al., 2009). There have been many studies concerning the genesis of dolomite. Mature theories of dolomitization include seepage-reflux dolomitization (Adams and Rhodes, 1960), mixed-water dolomitization (Hanshaw et al., 1971), burial dolomitization (Heydari, 1997), and hydrothermal dolomitization (Davies et al., 2006). In China, there has been much research on the genesis of Ordovician dolomite in the central and northern portion of the Tarim Basin. This research has revealed seepage-reflux dolomitization, burial dolomitization, hydrothermal dolomitization, and mixed-water dolomitization (Gu, 2000; Yang et al., 2000; Zheng et al., 2012; Zhang et al., 2013). In the Lower Paleozoic, the thickness of the dolomite stratum ranges from 1560-1692 m (Peng et al., 2002), with a huge reservoir of hydrocarbon. Although the paleokarst reservoir in the Yingshan Formation has been a key formation for oil and gas exploration and development in recent years, research concerning the genesis of dolomite in the Penglaiba Formation has been relatively scarce. The question as to whether or not hydrothermal dolomitization exists in this formation remains to be answered, and the feature of its dolomitization fluid still require investigation. In addition, a model for dolomite genesis has yet to be develop.

For the dolomitization mode of the Tarim Basin, Gu (2000) indicated that there are two types of genetic mechanisms: penecontemporaneous dolomitization and burial dolomitization.Based on petrologic and geochemical features, Yang (2000) proposed mixed -water dolomitization. Meanwhile, by studying isotopes, rare earth elements (REEs) and thin sections, Zheng et al., (2012) indicated that there are three mechanisms: sabkha dolomitization, seepage-reflux dolomitization, and burial dolomitization. Among these studies, there is much controversy regarding the genesis of medium to coarse crystal dolomite, research concerning hydrothermal dolomitization has been relatively scarce, and there are problems with the period of hydrothermal dolomitization as well as the source of the hydrothermal fluid. In an attmpt to address these issues, this study used thin section and drill core observations, geochemical analysis, and an examination of the homogenization temperatures of fluid inclusions to investigate the genetic mechanisms of dolomite in the southwest Tarim Basin.

\section{Geological setting}

The Tarim Basin is the largest interior basin in China and features a complex tectonic and sedimentation history.Its fracture system is well-developed, with fracture depths reaching $60 \mathrm{~km}$ (Jia, 1995).The Tarim platform formed during the Yangzi movement in the Proterozoic, followed by the Caledonian, Hercynian, Indosinian, Yanshan, and Himalayan movements (Fig. 1). It also experienced three periods of volcanism, the first fromthe Sinian to Cambrian, the second from the Late Ordovician to Silurian, and the last from the Permian to Cretaceous, among which the strongest and largest was the period occurring during 


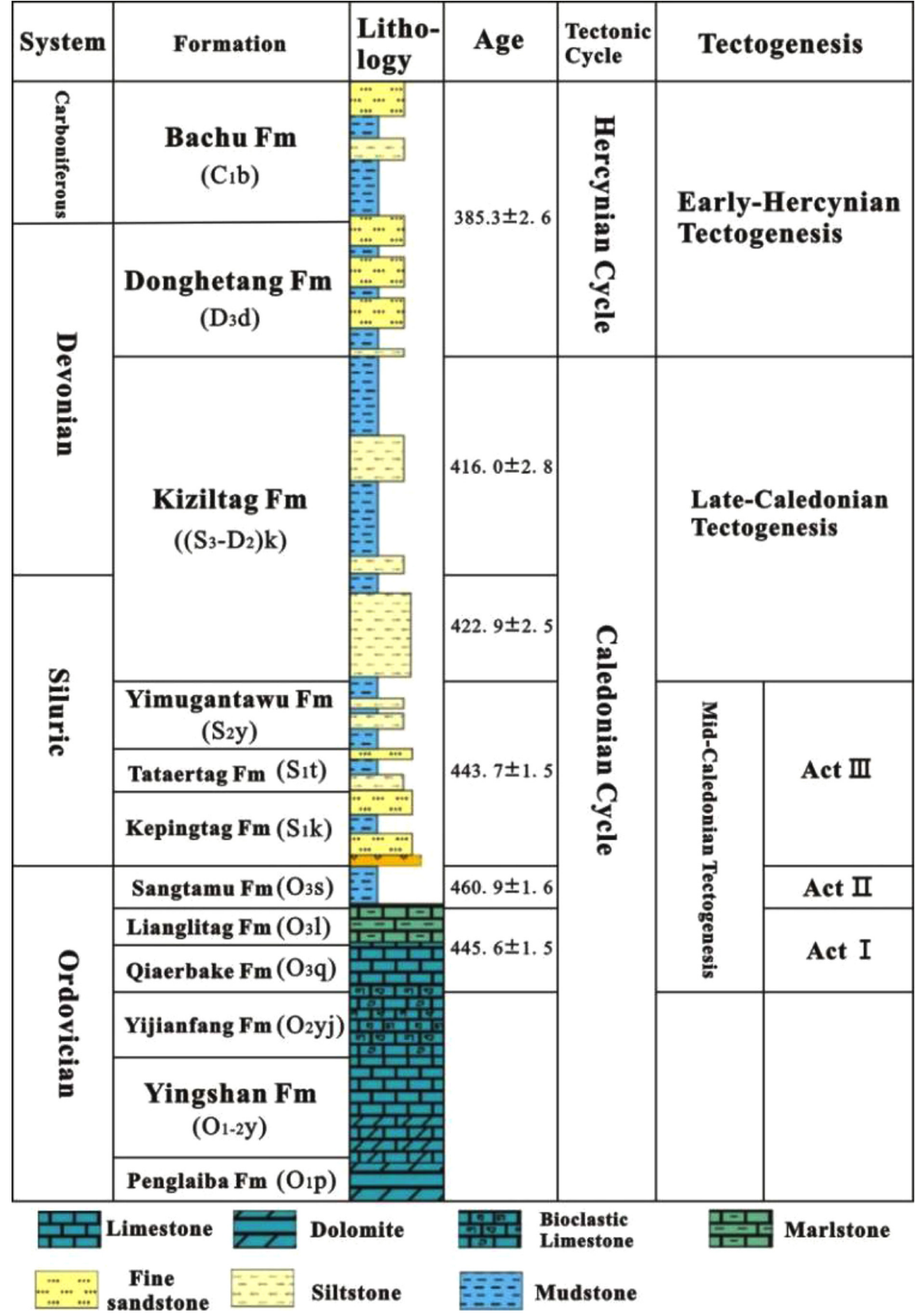

Figure 1. Stratigraphic column and tectonic history of the southwest Tarim Basin (Jia, 1995).

the basin, the Hetian paleohigh began to form, along with a series of thrust and fold belts southeast of Bamai, largely eroding Upper Ordovician strata and re-exposing Mid-Lower Ordovician strata. In the third phase, during the Early Hercynian, most of the Silurian and Devonian strata in the southwestern Tarim Basin were eroded due to the overall uplift of the basin and the further expansion of the Hetian paleohigh (Zhang et al., 2011; Du et al., 2013). Therefore, the Ordovician in Yubei, which unconformably contacts the overlying Carboniferous, mainly contains the Penglaiba, Yingshan, Lianglitage, and Sangtamu Formations (oldest to youngest), while the Yijianfang and Qiaerbake Formations have been eroded (Zhang, 2012). The sedimentary facies changed distinctly from the Penglaiba Formation to the Yingshan Formation. The sedimentary facies in the Penglaiba and lower Yingshan Formation range from restricted to open platform and the lithology is primarily dolomite. The upper Yingshan Formation is open platform while the lithology includes micrite limestone and grainstone. The lower part is a restricted platform and its lithology contains lime-dolomite and dolomite-limestone (Liu et al., 2015).

\section{Methods}

Samples were collected from drill cores of the Ordovician. Thin sections were made from these samples and examined using a polarizing microscope and cathodoluminescence (CL) in order to identify their petrographic characteristics. $\mathrm{C}$ and $\mathrm{O}$ isotope analyses were performed by the Petroleum Exploration and Production Research Institute of SINOPEC using a MAT 253 stable isotope ratio mass spectrometer and the $100 \%$ phosphoric acid method. Thermal reactions of $100 \%$ phosphoric acid and carbonate samples were conducted in vacuum conditions. The analyses of different minerals were per-

the Permian (Jia, 1995; He et al., 2005; Tang et al., 2009; Ding et al., 2012; Du et al., 2013).

The study area was located in the southwest Tarim Basin (Fig. 2) (Si et al., 2013), a region that has experienced 3 stages of tectonic uplift, i.e., the Middle Caledonian, Late Caledonian, and Early Hercynian (Zhang et al., 2011; Du et al., 2013), resulting in widely distributed karst reservoirs (Zhou, 2006; Kang, 2008). In Episode I, during the mid-Caledonian, the southern portion of the passive continental margin of th southwestern Tarim Basin was uplifted above the sea surface, and the Ordovician Yingshan Formation in the southern part of the Tarim Basin was chemically eroded and denuded due to southern compression and northern tension. In the second phase of the Late Caledonian, as a result of compression in the southeastern margin of formed under different isothermal reaction times and temperatures: $25 \pm 0.1^{\circ} \mathrm{C}$ (16 hours) for limestone and $50 \pm 0.1^{\circ} \mathrm{C}$ (36 hours) for dolomite. Carbon dioxide was collected, purified, and its carbon and oxygen isotopic composition analyzed using a MAT 253 stable isotope ratio mass spectrometer, calibrated to VPDB (Niu et al., 2017). Sr isotope was analyzed at the Chinese Academy of Sciences (CAS). Approximately $80 \mathrm{mg}$ of powder was dissolved in $2.5 \mathrm{~N} \mathrm{HCl}$ at a temperature of $80^{\circ} \mathrm{C}$; the solution was then loaded into a chromatographic column with $2 \mathrm{ml}$ of AG50Wx12 200e400 mesh cation exchange resin for separation of strontium from the sample matrix and measured using a MAT 262 thermal ionization mass spectrometer. For elemental analysis, a subset of sample powder was digested in $5 \%(\mathrm{v} / \mathrm{v})$ acetic acid for 70-80 min and analyzed for major, minor, and 


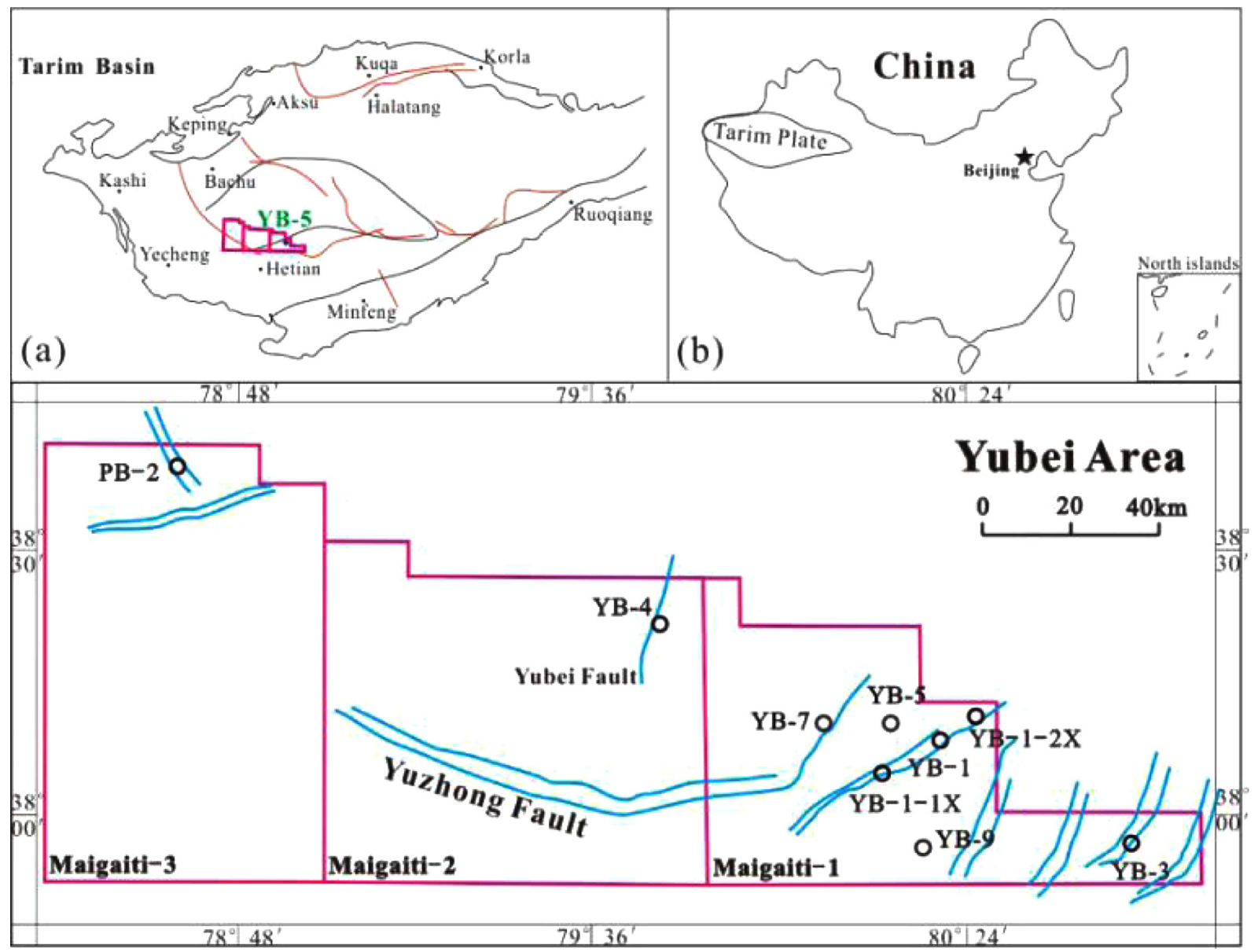

Figure 2. Location of the study area (Niu, et al. 2018).

rare earth elements (REEs) (Coleman et al., 1989) using a Neptune Plus MC-ICP-MS (Thermo Fisher).

Samples consisting of the matrix dolomite and calcite that filled in dissolved pores and fractures from the Yubei 5 and Yubei 7 wells were selected for fluid inclusion homogenization temperature testing, which was performed in the Micro Hydrocarbon Detection Laboratory using a Linkam THMS 600G type Cooling-Heating Stage linked by an Olympus microscope in CUG(China University of Geoscience). Analysis accuracy is $\pm 0.1^{\circ} \mathrm{C}$.

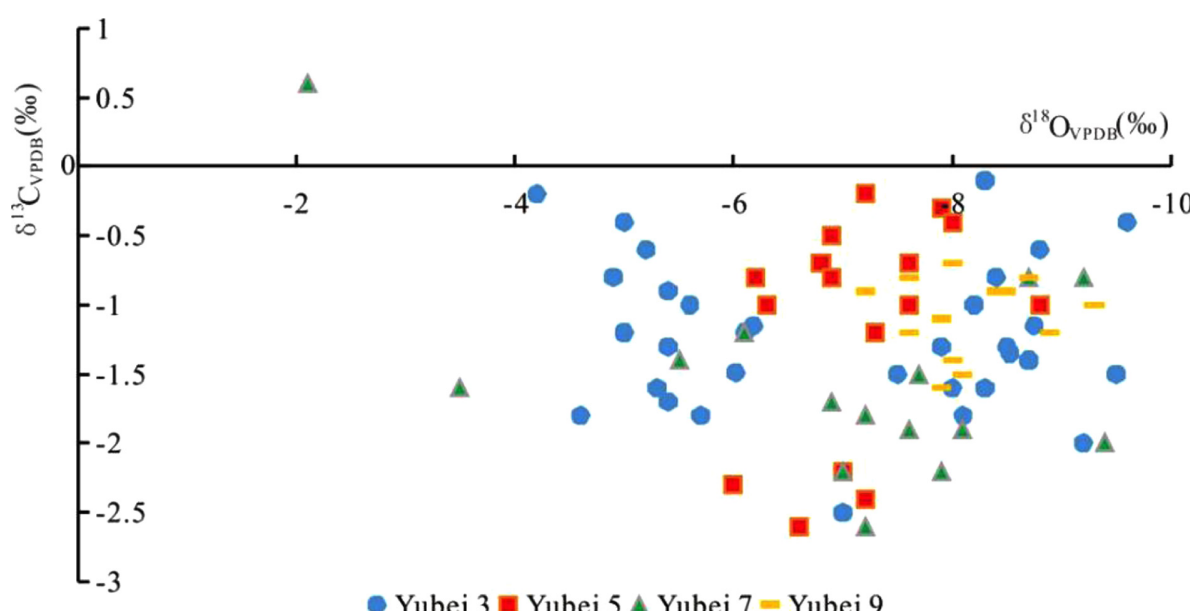

Figure 3. $C$ and $O$ isotopes of the Yubei 3, Yubei 5, Yubei 7, and Yubei 9 wells.

\section{Results}

The results showed that $\delta^{13} \mathrm{C}$ value ranged between $-2.6 \%$ and $0.7 \%$, averaging $-0.96 \%$, while $\delta^{18} \mathrm{O}$ values fluctuated between $-3.5 \%$ o and $-9.4 \%$, averaging $-6.84 \%$. The $\delta^{18} \mathrm{O}$ values of carbonates in the study area were lower than the $\delta^{18} \mathrm{O}$ values of Ordovician seawater. $\delta^{13} \mathrm{C}$ values were within the normal range for carbon isotope composition in carbonate rocks of the Ordovician marine environment (Veizer et al., 1999). However, there were differences between the wells (Fig. 3). The $\delta^{13} \mathrm{C}$ values of the Yubei 3 well ranged from $-2.5 \%$ and $-1.3 \%$, averaging $-1.78 \%$, while the $\delta^{18} \mathrm{O}$ values fluctuated from $-7.9 \%$ to $-5.6 \%$, averaging $-6.55 \%$. The $\delta^{13} \mathrm{C}$ values of carbonates in the Yubei 5 well mainly ranged from $0.6 \%$ to $-2.6 \%$, averaging $-0.88 \%$, and the $\delta^{18} \mathrm{O}$ values, which were the most enriched of all of the wells, varied mainly between $-7.6 \%$ and $-4 \%$, averaging $-5.9 \%$. The $\delta^{13} \mathrm{C}$ values of the Yubei 7 well were between $-2.6 \%$ and $-0.8 \%$, averaging $-1.6 \%$, while the $\delta^{18} \mathrm{O}$ values fluctuated from $-9.4 \%$ o to $-3.5 \%$, averaging $-7.12 \%$. The $\delta^{13} \mathrm{C}$ and $\delta^{18} \mathrm{O}$ values of the Yubei 9 well ranged from $-1.6 \%$ to $0.7 \%$ and $-9.3 \%$ to $-4.7 \%$, averag- 
ing $-0.49 \%$ and $-7.25 \%$ respectively. The $\mathrm{Sr}$ content was $22.2-153.8$ $\mu \mathrm{g} / \mathrm{g}$, with an average value of $89.6 \mu \mathrm{g} / \mathrm{g} ;{ }^{87} \mathrm{Sr} /{ }^{86} \mathrm{Sr}$ was $0.7087-0.7104$, with an average value of 0.7092 . The fluid inclusion homogenization temperature ranged from $100-210^{\circ} \mathrm{C}$ and could be divided into 3 groups. Detailed information can be found in following tables.

\section{Discussion}

\section{Petrologic Features}

Based cores and well logging, the lithology of the Penglaiba Formation was found to be primarily dolomite in the eastern portion of the study area. The occurrence patterns of dolomite included scattered, along with stylolite, lumped, and dolomite filled within pores. In addition, there was also some saddle dolomite in fractures and dissolved pores.

Based on grain size, dolomite in the southwestern Tarim Basin included silty, fine, medium, and coarse (Fig. 4). The grain size of the silty dolomite was $0.03-0.1 \mathrm{~mm}$, the color of the drill core was gray, and it exhibited a massive structure, with fractures (Fig. 4a).

The fine dolomite grain size ranged from $0.1-0.25 \mathrm{~mm}$ and the color of the drill cores was off-white (Fig. 4b). Under the microscope, the dolomite appeared to be euhedral to subhedral, with an interlocked structure (Fig. 4c). The character of the medium dolomite is shown in Fig 4e. Most of the dolomite was subhedral, and the grain size varied from $0.25-0.5 \mathrm{~mm}$ (Fig. 4d). And the silt and fine dolomite is the main part in Penglaib Formation and Lower Yingshan Formation.

Coarse dolomite mainly developed in the lower portion of the Penglaiba Formation, its color was basically dark gray, it exhibited a massive structure with many fractures and dissolved pores (Fig. 4e), and the crystals were euhedral to subhedral. The misty center with bright rim structure is very clear (Fig. 4f).

Scattered monocrystalline dolomite and porphyritic distributed dolomite were relatively rare, and mainly distributed in the Yingshan Formation, as well as in the stylolite and deep portion of the Penglaiba Formation (Fig. 4g). Dolomite cement filled in fractures and pores can be observed in the study area, along with metasomatic relict texture (Fig. 4h).

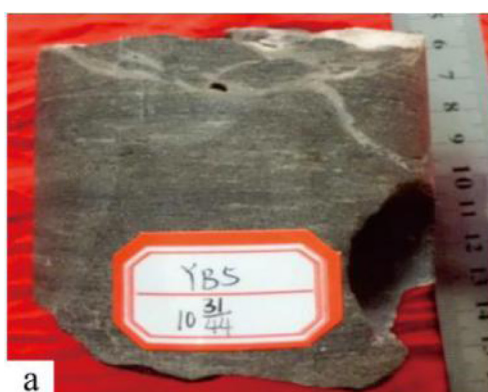

a
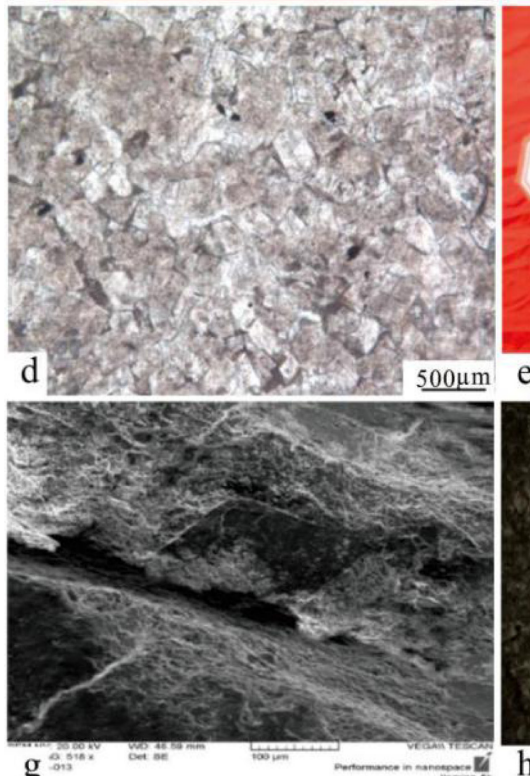

$\mathrm{g}$
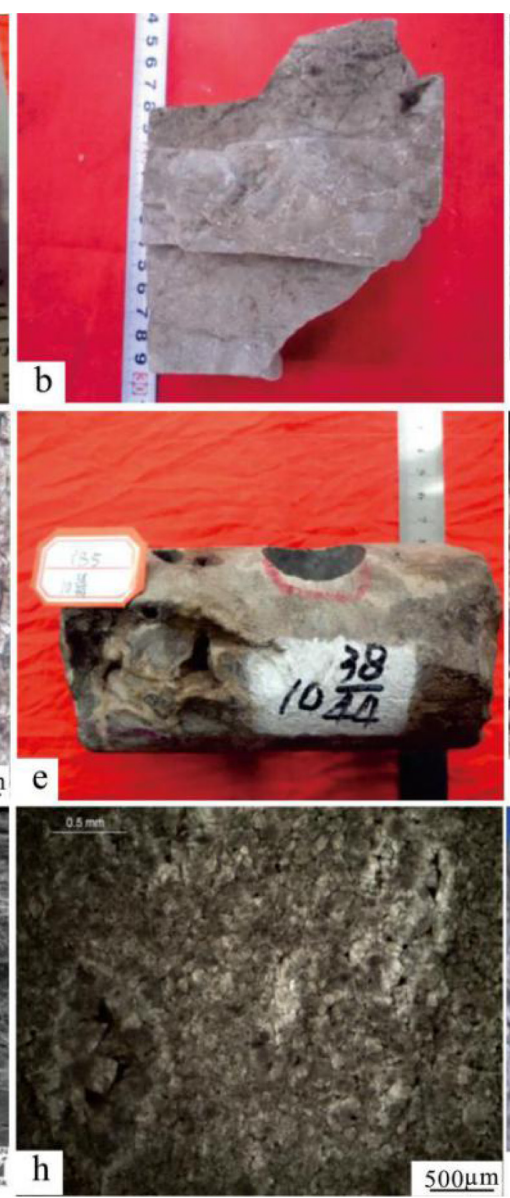
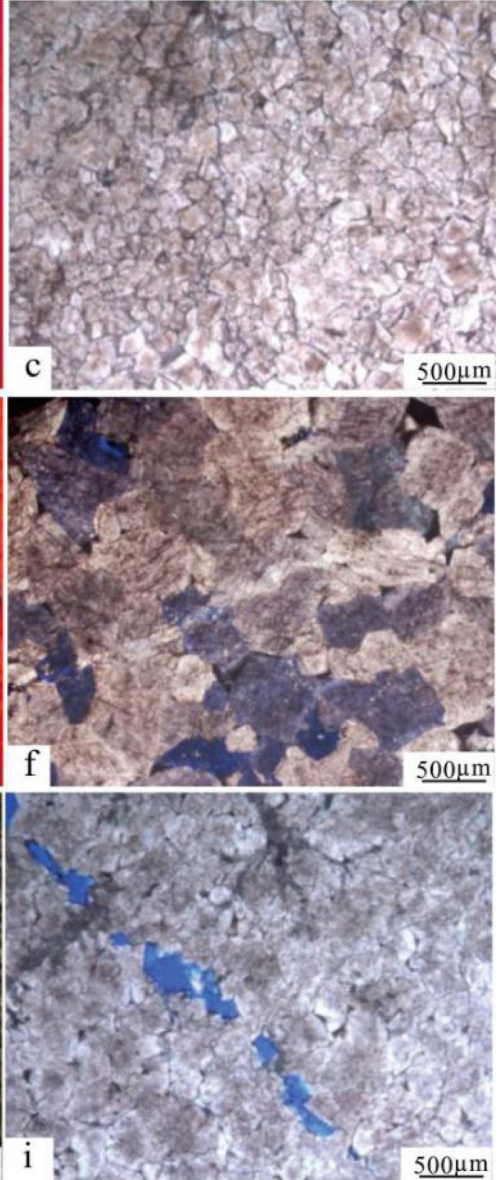

Figure 4. Drill core and thin section features of Ordovician dolomite in the Yubei area.(a: Yubei 5 well, Penglaiba Formation, 6619.15 m, gray silty dolomite with fractures; b: Yubei 5 well, Penglaiba Formation, 6719.15 m, off-white lumped fine dolomite; c: Yubei 5 well, Penglaiba Formation, 6714.1 m, subhedral fine; d: Yubei 5 well, Penglaiba Formation, 6756.2 m, euhedral to subhedral medium dolomite with a misty center and bright rim; e: Yubei 5 well, Penglaiba Formation, $6762.2 \mathrm{~m}$, coarse dolomite with dissolved pores; $f$ : Yubei 5 well, Penglaiba Formation, $6762.2 \mathrm{~m}$, euhedral to subhedral coarse dolomite; g: Pishanbei 2 well, Yingshan Formation, 7190.6 m, SEM, dolomite formed along the stylolite; $h$ : Yudong 4 well, Yingshan Formation, 5543.68 m, medium dolomite, residual limestone on dolomite. $i$ : Yubei 3 well, Penglaiba Formation, 5449.36 m, gnamma hole). 
Table 1. Cand $O$ isotope characteristics in southwest of Tarim Basin

\begin{tabular}{|c|c|c|c|c|c|}
\hline \multirow{2}{*}{ Well } & \multirow{2}{*}{ Depth (m) } & \multirow{2}{*}{ Formation } & \multirow{2}{*}{ Lithology } & $\delta^{18} \mathrm{O}_{\mathrm{VPDB}}$ & $\delta^{13} \mathrm{C}_{\mathrm{VPDB}}$ \\
\hline & & & & $(\%)$ & $(\%)$ \\
\hline Yubei 3 & 5165.00 & Yingshan & limestone & -9.50 & -1.50 \\
\hline Yubei 3 & 5166.00 & Yingshan & limestone & -8.70 & -1.40 \\
\hline Yubei 3 & 5170.30 & Yingshan & limestone & -9.20 & -2.00 \\
\hline Yubei 3 & 5172.10 & Yingshan & limestone & -8.10 & -1.80 \\
\hline Yubei 3 & 5174.02 & Yingshan & limestone & -8.00 & -1.60 \\
\hline Yubei 3 & 5175.50 & Yingshan & limestone & -7.50 & -1.50 \\
\hline Yubei 3 & 5176.40 & Yingshan & limestone & -8.70 & -1.40 \\
\hline Yubei 3 & 5258.75 & Yingshan & limestone & -7.00 & -2.50 \\
\hline Yubei 3 & 5260.30 & Yingshan & limestone & -5.60 & -1.00 \\
\hline Yubei 3 & 5265.06 & Yingshan & limestone & -7.90 & -1.30 \\
\hline Yubei 3 & 5278.01 & Yingshan & limestone & -8.30 & -1.60 \\
\hline Yubei 3 & 5280.50 & Yingshan & limestone & -5.70 & -1.80 \\
\hline Yubei 3 & 5258.30 & Yingshan & limestone & -6.02 & -1.49 \\
\hline Yubei 3 & 5264.00 & Yingshan & limestone & -8.75 & -1.15 \\
\hline Yubei 3 & 5265.30 & Yingshan & limestone & -8.53 & -1.35 \\
\hline Yubei 3 & 5358.17 & Yingshan & limestone & -8.40 & -0.80 \\
\hline Yubei 3 & 5358.40 & Yingshan & dolomitic limestone & -8.50 & -1.30 \\
\hline Yubei 3 & 5360.26 & Yingshan & limestone & -9.60 & -0.40 \\
\hline Yubei 3 & 5363.39 & Yingshan & limestone & -8.30 & -0.10 \\
\hline Yubei 3 & 5366.26 & Yingshan & limestone & -8.80 & -0.60 \\
\hline Yubei 3 & 5370.02 & Yingshan & limestone & -8.40 & -0.80 \\
\hline Yubei 3 & 5444.25 & Yingshan & limestone & -5.40 & -0.90 \\
\hline Yubei 3 & 5445.72 & Yingshan & limestone & -6.10 & -1.20 \\
\hline Yubei 3 & 5447.90 & Yingshan & limestone & -5.00 & -1.20 \\
\hline Yubei 3 & 5449.62 & Yingshan & limestone & -5.20 & -0.60 \\
\hline Yubei 3 & 5450.86 & Yingshan & limestone & -4.20 & -0.20 \\
\hline Yubei 3 & 5452.53 & Yingshan & limestone & -4.90 & -0.80 \\
\hline Yubei 3 & 5454.66 & Yingshan & limestone & -5.00 & -0.40 \\
\hline Yubei 3 & 5494.23 & Yingshan & limestone & -5.30 & -1.60 \\
\hline Yubei 3 & 5496.20 & Yingshan & limestone & -5.40 & -1.70 \\
\hline Yubei 3 & 5497.84 & Yingshan & limestone & -4.60 & -1.80 \\
\hline Yubei 3 & 5260.20 & Yingshan & dolomite & -5.40 & -1.30 \\
\hline Yubei 3 & 5262.40 & Yingshan & dolomite & -6.18 & -1.15 \\
\hline Yubei 3 & 5262.80 & Yingshan & dolomite & -8.20 & -1.00 \\
\hline Yubei 5 & 5995.80 & Yingshan & limestone & -7.20 & -2.40 \\
\hline Yubei 5 & 5997.60 & Yingshan & limestone & -6.60 & -2.60 \\
\hline Yubei 5 & 5999.20 & Yingshan & limestone & -6.00 & -2.30 \\
\hline Yubei 5 & 6001.90 & Yingshan & limestone & -7.00 & -2.20 \\
\hline Yubei 5 & 6605.30 & Penglaiba & dolomite & -7.90 & -0.30 \\
\hline Yubei 5 & 6605.53 & Penglaiba & middle dolomite & -6.80 & -0.70 \\
\hline Yubei 5 & 6605.95 & Penglaiba & middle dolomite & -6.20 & -0.80 \\
\hline Yubei 5 & 6606.50 & Penglaiba & middle dolomite & -6.90 & -0.50 \\
\hline Yubei 5 & 6607.66 & Penglaiba & middle-coarse dolomite & -7.60 & -0.70 \\
\hline Yubei 5 & 6740.10 & Penglaiba & middle dolomite & -8.80 & -1.00 \\
\hline Yubei 5 & 6743.27 & Penglaiba & middle-coarse dolomite & -7.60 & -1.00 \\
\hline
\end{tabular}


Table 1. Continued

\begin{tabular}{|c|c|c|c|c|c|}
\hline \multirow{2}{*}{ Well } & \multirow{2}{*}{ Depth (m) } & \multirow{2}{*}{ Formation } & \multirow{2}{*}{ Lithology } & $\delta^{18} \mathrm{O}_{\mathrm{VPDB}}$ & $\delta^{13} \mathrm{C}_{\mathrm{VPDB}}$ \\
\hline & & & & $(\%)$ & $(\%)$ \\
\hline Yubei 5 & 6744.10 & Penglaiba & coarse dolomite & -7.30 & -1.20 \\
\hline Yubei 5 & 6744.17 & Penglaiba & middle-coarse dolomite & -6.30 & -1.00 \\
\hline Yubei 5 & 6839.90 & Penglaiba & coarse dolomite & -6.90 & -0.80 \\
\hline Yubei 5 & 6841.82 & Penglaiba & coarse dolomite & -7.20 & -0.20 \\
\hline Yubei 5 & 6842.10 & Penglaiba & coarse dolomite & -8.00 & -0.40 \\
\hline Yubei 7 & 5805.00 & Yingshan & limestone & -8.10 & -1.90 \\
\hline Yubei 7 & 5806.00 & Yingshan & limestone & -7.60 & -1.90 \\
\hline Yubei 7 & 5807.00 & Yingshan & limestone & -7.90 & -2.20 \\
\hline Yubei 7 & 5807.45 & Yingshan & limestone & -2.10 & 0.60 \\
\hline Yubei 7 & 5807.90 & Yingshan & limestone & -9.40 & -2.00 \\
\hline Yubei 7 & 5808.90 & Yingshan & limestone & -7.70 & -1.50 \\
\hline Yubei 7 & 5810.39 & Yingshan & limestone & -7.20 & -1.80 \\
\hline Yubei 7 & 5825.20 & Yingshan & limestone & -7.00 & -2.20 \\
\hline Yubei 7 & 5827.10 & Yingshan & limestone & -7.20 & -2.60 \\
\hline Yubei 7 & 6230.20 & Penglaiba & silt-fine dolomite & -6.90 & -1.70 \\
\hline Yubei 7 & 6230.90 & Penglaiba & silt-fine dolomite & -6.10 & -1.20 \\
\hline Yubei 7 & 6232.02 & Penglaiba & silt-fine dolomite & -3.50 & -1.60 \\
\hline Yubei 7 & 6233.29 & Penglaiba & silt-fine dolomite & -5.50 & -1.40 \\
\hline Yubei 7 & 6371.50 & Penglaiba & coarse dolomite & -9.20 & -0.80 \\
\hline Yubei 7 & 6373.59 & Penglaiba & coarse dolomite & -8.70 & -0.80 \\
\hline Yubei 9 & 6845.54 & Yingsahn & dolomite & -8.00 & -0.70 \\
\hline Yubei 9 & 6846.59 & Yingsahn & dolomite & -8.00 & -0.70 \\
\hline Yubei 9 & 6848.10 & Yingsahn & dolomite & -7.60 & -0.80 \\
\hline Yubei 9 & 6849.05 & Yingsahn & dolomite & -7.90 & -1.10 \\
\hline Yubei 9 & 6845.54 & Yingsahn & limestone & -8.00 & -0.70 \\
\hline Yubei 9 & 6845.60 & Yingsahn & limestone & -8.40 & -0.90 \\
\hline Yubei 9 & 6846.59 & Yingsahn & limestone & -8.00 & -0.70 \\
\hline Yubei 9 & 6847.59 & Yingsahn & limestone & -8.70 & -0.80 \\
\hline Yubei 9 & 6848.10 & Yingsahn & limestone & -7.60 & -0.80 \\
\hline Yubei 9 & 6848.70 & Yingsahn & limestone & -8.50 & -0.90 \\
\hline Yubei 9 & 6849.05 & Yingsahn & limestone & -7.90 & -1.10 \\
\hline Yubei 9 & 6878.93 & Yingsahn & limestone & -9.30 & -1.00 \\
\hline Yubei 9 & 6879.73 & Yingsahn & limestone & -7.20 & -0.90 \\
\hline Yubei 9 & 6881.35 & Yingsahn & limestone & -8.40 & -0.90 \\
\hline Yubei 9 & 6881.70 & Yingsahn & limestone & -8.10 & -1.50 \\
\hline Yubei 9 & 6883.67 & Yingsahn & limestone & -8.00 & -1.40 \\
\hline Yubei 9 & 6884.27 & Yingsahn & limestone & -7.60 & -1.20 \\
\hline Yubei 9 & 6884.67 & Yingsahn & limestone & -7.90 & -1.60 \\
\hline Yubei 9 & 6885.50 & Yingsahn & limestone & -8.90 & -1.20 \\
\hline
\end{tabular}

\section{C and O Isotopes}

Carbon and oxygen isotopes of carbonate rocks are closely related to the sedimentary environment (Veizer et al., 1999). In the study area, $\delta^{13} \mathrm{C}$ values within most carbonate samples ranged from $-2 \%$ to $2 \%$, which corresponded well with normal marine carbonate rocks. $\delta^{18} \mathrm{O}$ values however, varied from $-3.5 \%$ to $-9.4 \%$ (Fig. 3 and Table 1), which are lower than values found in normal marine carbonate rocks (Zhang, 1985; Niu et al., 2017). In the Lower Ordovician, the $\delta^{13} \mathrm{C}$ values of marine carbonate ranges from $-1.5 \%$ to $0.5 \%$ (Veizer et al., 1999). In 
the study area, $\delta^{13} \mathrm{C}$ values of dolomite in Penglaiba Formation ranged between $-1.7 \%$ and $-0.2 \%$, levels that are quite similar to the values of limestone. In addition, the type of dolomite in the study area was mainly silt-fine crystals, thus indicating that most of the dolomitization fluid in study area was from Ordovician seawater, and the dolomite should be contemporaneous or penecontemporaneous (Land, 1985).

The study area included deep and shallow burial environments. In deep buried diagenetic environments, the diagenetic fluid is basin brine with complex chemical components formed by long-term rock-water interaction under high temperature and pressure, while diagenetic fluid in shallow buried diagenetic environments is mainly a mixture of seawater and atmospheric fresh water (Qiang, 1998). The drill core characteristics indicated that the stylolite and fractures had positive correlations with dolomite distributed nearby in both the Yingshan and upper Penglaiba Formations that formed a porphyric structure. This is soild evidence suggesting that this kind of dolomite formed after the stylolite in a deep burial environment. Another notable piece of evidence is that, as depth increased, the content of larger and more euhedral crystal increased. Values of $\delta^{18} \mathrm{O}$ and $\delta^{13} \mathrm{C}$ among limestone, fine-silt dolomite, and middle-coarse dolomite did not change independently, which means these three types of carbonate should originally have the same type of diagenetic fluid. In terms of geological setting, restricted platform facies developed in the lower part of the Yingshan Formation and the Penglaiba Formation; in other words, the sedimentary environment gradually changed from relatively arid to more humid from the lower Penglaiba Formation to the upper Yingshan Formation (Liu et al., 2015). The sediments accumulated in the Penglaiba Formation and lower part of the Yingshan Formation would provide Mg-rich fluid during the burial diagenesis period (Ding et al., 2012; Niu et al., 2017). Considering the sedimentary environment, this kind of dolomite should be burial dolomite, and given the similar values of the $\mathrm{C}$ isotope, this burial dolomite should originate from the recrystallization of contemporaneous and penecontemporaneous dolomite. In addition, gypsolyte has not been found in drill cores or well logging (Niu et al., 2017), indicating that there is no abundant Mg-rich fluid for burial dolomitization. This probably explains why the burial dolomite did not form a continuous layer.

Previous studies have indicated that dolomite influenced by meteoric water will have a more negative $\delta^{18} \mathrm{O}$ value (Meyers et al., 1997; Li et al., 2013). According to Huang (Huang, 2014), the $\delta^{18} \mathrm{O}$ value of the original dolomite formed in the Lower Ordovician of the southwestern Tarim Basin ranges from $-7.0 \%$ and $5.0 \%$. In the study area, a larger portion of the $\delta^{18} \mathrm{O}$ values in the Penglaiba Formation were found to be less than $-7.0 \%$, and the average of all values was $-7.08 \%$, which is a more negative value than that of the original dolomite. In terms of geological setting, there may be 2 reasons for this difference. The first may be the uplift of the Ordovician stratum, which was associated with the leaching of meteoric water (Meyers et al., 1997). Another may involve the water-rock interaction in the deep burial environment. In addition, dissolution is pervasive in the middle of the Penglaiba Formation. Based on the characteristics of the thin sections, erosion across both rock particles and cement can be observed (Fig. 4i). It is clear that dissolution in the formation should be non-selective, and the crystal and cement were dissolved during the same period. In the Yubei 5 well, dissolution pores gradually decreased from base to top, thus suggesting that acidic fluid was constantly consumed as it was transported upward along the deep faults (Niu et al., 2017).
The combination of geochemical data, petrologic features, and geological background suggests that dolomitization in the study area was primarily contemporaneous to penecontemporaneous, with burial dolomitization distributed along the stylolite, fractures, and deep part of the Penglaiba Formation, with many fractures and corrosion pores.

\section{Sr Isotope Characteristics}

There are four isotope forms for $\mathrm{Sr}:{ }^{84} \mathrm{Sr},{ }^{86} \mathrm{Sr},{ }^{87} \mathrm{Sr}$, and ${ }^{88} \mathrm{Sr}$. As one of the most important elements, $\mathrm{Sr}$ has a close relationship with carbonate diagenesis. In addition, the $\mathrm{Sr}$ isotope is homogeneous and globally unified, and the value of the $\mathrm{Sr}$ isotope in seawater is fixed within a given period. The length of time that $\mathrm{Sr}$ exists in seawater is much longer than the mixing time of seawater, thus making ${ }^{87} \mathrm{Sr} r{ }^{86} \mathrm{Sr}$ a function of time (Allen et al., 1993). Therefore, the $\mathrm{Sr}$ isotope can be used as a tool to track the fluid and determine the dolomitization time (Huang et al., 2002; Liu et al., 2007; Yun et al., 2008).

It has been pointed out that the value of ${ }^{87} \mathrm{Sr} /{ }^{86} \mathrm{Sr}$ is mainly controlled by seawater change. During the Cambrian, the value of this ratio ranged from 0.709-0.7095, while in the Ordovician it varied from 0.708-0.709 (Allen et al., 1993; Shields et al., 2003). Based on previous research in the Tarim Basin, during the Middle to Lower Ordovician, the ${ }^{87} \mathrm{Sr}{ }^{86} \mathrm{Sr}$ value ranged from $0.708673-0.708889$, with an average value of 0.7087696 (Liu et al., 2007). During the Lower Ordovician, the ${ }^{87} \mathrm{Sr}{ }^{86} \mathrm{Sr}$ value varied between $0.708710-0.708910$, with an average of 0.708873 (Jiang et al., 2002). As the results in Table 2 and Fig. 5 show, in the study area, the ${ }^{87} \mathrm{Sr} /{ }^{86} \mathrm{Sr}$ values for middle-coarse dolomite and siliceous dolomite were clearly higher than the values for limestone and silt-fine dolomite, only one sample, the ${ }^{87} \mathrm{Sr}{ }^{86} \mathrm{Sr}$ values is in Ordovician part. The ${ }^{87} \mathrm{Sr}{ }^{86} \mathrm{Sr}$ values of limestone and silt-fine dolomite basically fell within those of the Ordovician, also indicating that silt-fine dolomite is contemporaneous-penecontemporaneous and the dolomitization fluid was Ordovician seawater. As previously indicated in this study, middlecoarse dolomite was burial dolomite, which, although it should have the same ${ }^{87} \mathrm{Sr}{ }^{86} \mathrm{Sr}$ value range, clearly exhibitited a higher value. In the Tarim Basin, the fault and fracture systems are highly developed. According to Cai Chunfang et al., (2008) and Zhao Chuang et al., (2012), hydrothermal fluid derived from Precambrian clastic rocks crossed the Cambrian and was transported upwards through the fault system of the Cambrian and Ordovician that developed over the course of geological history. The ${ }^{87} \mathrm{Sr} /{ }^{86} \mathrm{Sr}$ ratio of ancient clastic rocks is approximately 0.720 (Graham and Langhorne, 2006), and ${ }^{87} \mathrm{Sr}$-rich fluid interacted with dolomite in the deep part of the Ordovician, elevating the value of ${ }^{87} \mathrm{Sr} /{ }^{86} \mathrm{Sr}$.

As the diagenetic process continued, Sr content in the carbonate gradually decreased. Dolomite that formed during the early diagenesis stage would probably have $\mathrm{Sr}$ content greater than $550 \mu \mathrm{g} / \mathrm{g}$ (Tucker et al., 1990), while the Sr content within dolomite that formed during the later diagenesis stage would be relatively low. If the dolomitization occurred later, the calcite for dolomitization would be stable and have low $\mathrm{Sr}$ content. As a result, the $\mathrm{Sr}$ content within the dolomite would be low. In addition, the hydrothermal and recrystallization processes would also lead to a decrease of Sr (Ihsan, 2003; Huang, et al., 2006; Kirmaci et al., 2005).

Previous research demonstrated that, in the Tarim Basin, dolomite formed during the later stages of diagenesis, the burial depths were 
Table 2. Sr isotope characteristics in southwest of Tarim Basin

\begin{tabular}{|c|c|c|c|c|}
\hline Lithology & Well & Formation & $\operatorname{Depth}(\mathrm{m})$ & ${ }^{87} \mathrm{Sr} /{ }^{86} \mathrm{Sr}$ \\
\hline limestone & Yubei 7 & Yingshan & 5806.9 & 0.7087 \\
\hline limestone & Yubei 7 & Yingshan & 5808.39 & 0.7088 \\
\hline limestone & Yubei 7 & Yingshan & 5815.2 & 0.7088 \\
\hline limestone & Yubei 7 & Yingshan & 5818.1 & 0.7088 \\
\hline dolomitic limestone & Yubei 7 & Penglaiba & 6231.02 & 0.709 \\
\hline dolomitic limestone & Yubei 7 & Penglaiba & 6232.29 & 0.7104 \\
\hline calcitic dolomite & Yubei 5 & Yingshan & 5989.8 & 0.7089 \\
\hline calcitic dolomite & Yubei 5 & Yingshan & 5992.6 & 0.7089 \\
\hline siliceous dolomite & Yubei 5 & Yingshan & 5993.2 & 0.709 \\
\hline siliceous dolomite & Yubei 5 & Yingshan & 6003.86 & 0.7091 \\
\hline siliceous dolomite & Yubei 5 & Yingshan & 6005.3 & 0.7094 \\
\hline siliceous dolomite & Yubei 3 & Yingshan & 5354 & 0.70905 \\
\hline siliceous dolomite & Yubei 3 & Yingshan & 5354.5 & 0.70924 \\
\hline siliceous dolomite & Yubei 3 & Yingshan & 5364.5 & 0.70926 \\
\hline siliceous dolomite & Yubei 3 & Yingshan & 5374 & 0.7093 \\
\hline siliceous dolomite & Yubei 3 & Yingshan & 5364 & 0.7095 \\
\hline silt-fine dolomite & Yubei 3 & Yingshan & 5444 & 0.70875 \\
\hline silt-fine dolomite & Yubei 3 & Yingshan & 5444.5 & 0.70878 \\
\hline silt-fine dolomite & Yubei 3 & Yingshan & 5454 & 0.70884 \\
\hline silt-fine dolomite & Yubei 3 & Yingshan & 5454.4 & 0.70885 \\
\hline silt-fine dolomite & Yubei 3 & Yingshan & 5454.2 & 0.70887 \\
\hline silt-fine dolomite & Yubei 3 & Yingshan & 5454.3 & 0.7088 \\
\hline silt-fine dolomite & Yubei 3 & Yingshan & 5444 & 0.70886 \\
\hline silt-fine dolomite & Yubei 3 & Yingshan & 5494 & 0.7087 \\
\hline silt-fine dolomite & Yubei 3 & Yingshan & 5484 & 0.70882 \\
\hline silt-fine dolomite & Yubei 3 & Yingshan & 5484.5 & 0.70885 \\
\hline silt-fine dolomite & Yubei 7 & Penglaiba & 6222.2 & 0.7089 \\
\hline silt-fine dolomite & Yubei 7 & Penglaiba & 6227.9 & 0.7088 \\
\hline middle dolomite & Yubei 5 & Penglaiba & 6605.53 & 0.7098 \\
\hline middle dolomite & Yubei 5 & Penglaiba & 6605.95 & 0.7094 \\
\hline middle dolomite & Yubei 5 & Penglaiba & 6606.5 & 0.7092 \\
\hline middle-coarse dolomite & Yubei 5 & Penglaiba & 6607.66 & 0.7092 \\
\hline middle dolomite & Yubei 5 & Penglaiba & 6740.1 & 0.7093 \\
\hline middle-coarse dolomite & Yubei 5 & Penglaiba & 6743.27 & 0.7094 \\
\hline coarse dolomite & Yubei 5 & Penglaiba & 6744.1 & 0.70901 \\
\hline middle-coarse dolomite & Yubei 5 & Penglaiba & 6744.17 & 0.70923 \\
\hline coarse dolomite & Yubei 5 & Penglaiba & 6839.9 & 0.70872 \\
\hline coarse dolomite & Yubei 5 & Penglaiba & 6841.82 & 0.70907 \\
\hline coarse dolomite & Yubei 5 & Penglaiba & 6842.1 & 0.70912 \\
\hline coarse dolomite & Yubei 5 & Penglaiba & 6843.2 & 0.70945 \\
\hline coarse dolomite & Yubei 5 & Penglaiba & 6843.79 & 0.70971 \\
\hline
\end{tabular}




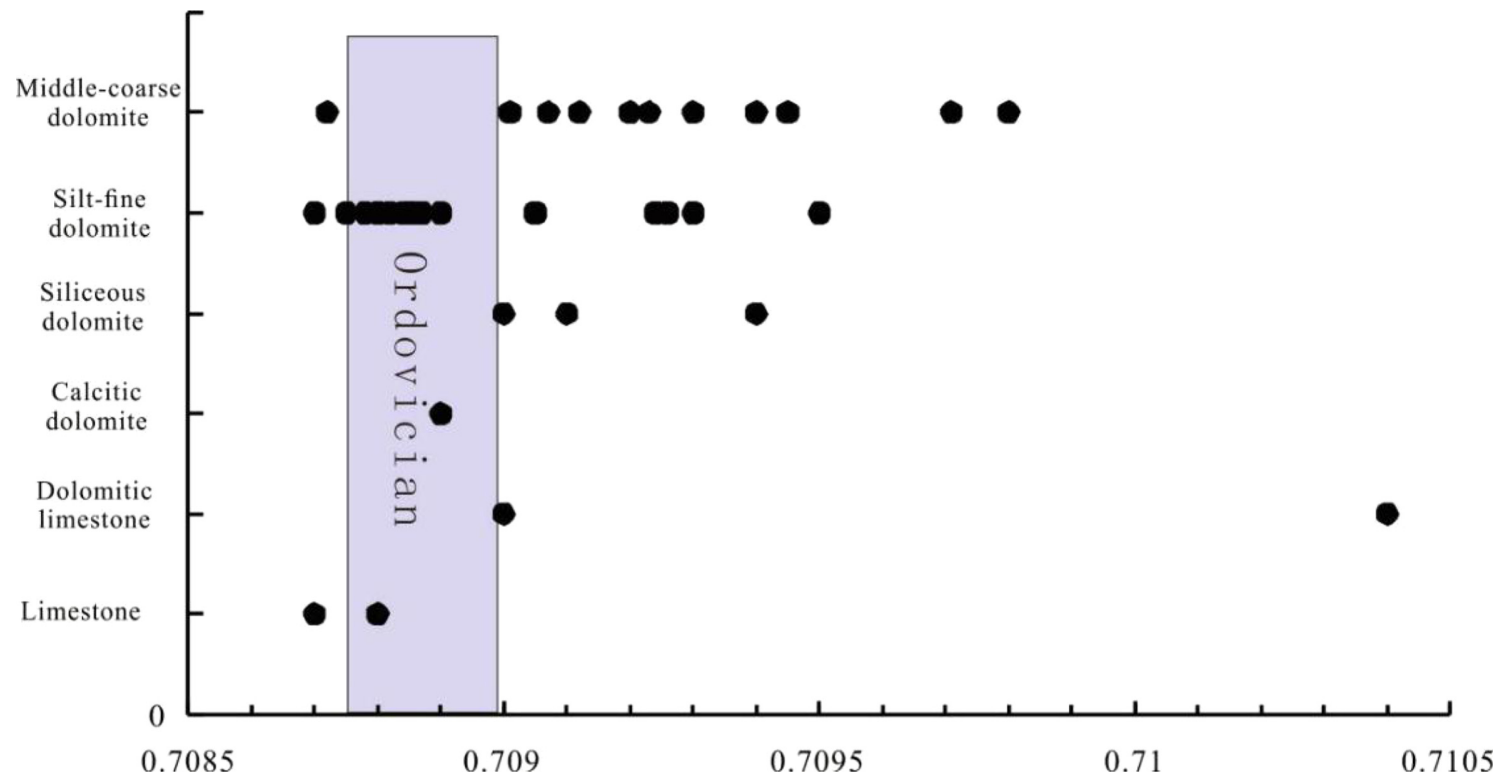

Figure 5. Sr isotope characteristics of limestone and dolomite in the southwest Tarim Basin.

Table 3. Sr content in southwest of Tarim Basin

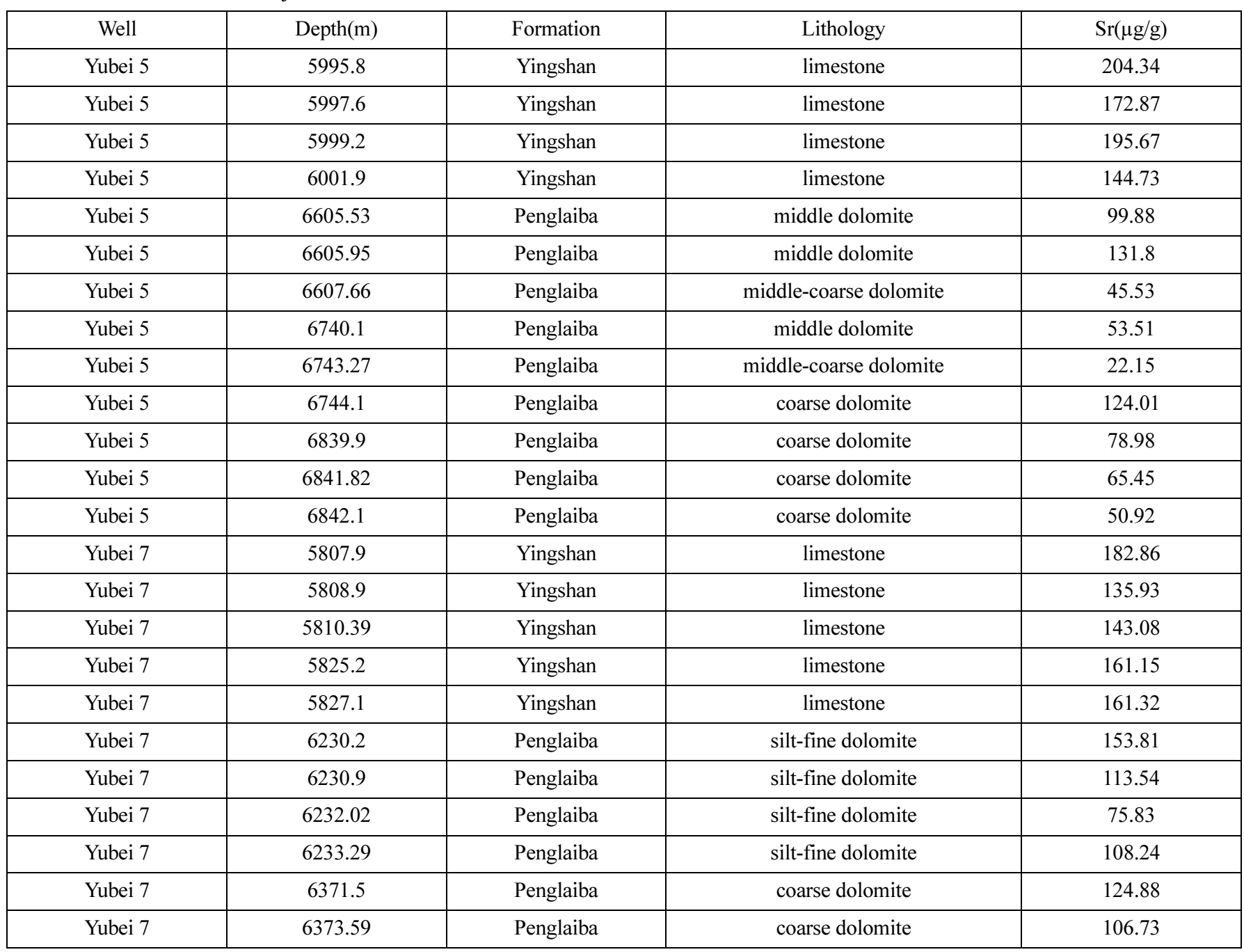

relatively large in the Tazhong, Bachu, and Yingmaili areas, and the average Sr content was $72 \mu \mathrm{g} / \mathrm{g}$ (Zhang and Luo, 2010). As can be seen in
Table 3, within the study area the Sr content of the dolomite ranged from $22.2-153.8 \mu \mathrm{g} / \mathrm{g}$, with an average value of $89.6 \mu \mathrm{g} / \mathrm{g}$. It is nota- 
ble that the Sr content was high in limestone. Combined with the hydrothermal minerals and burial dolomite, it can be concluded that the drop in Sr content was caused by the hydrothermal and recrystallization processes of contemporaneous-penecontemporaneous dolomite.

\section{Rare Earth Elements (REEs)}

The rare earth elements (REEs) are important trace chemical species. To further study the dolomitization fluid source, 12 different types of samples from the Penglaiba Formation within the study area were tested. As we can see from the results in Tables 4 and 5 and Figs. 6 and 7 (standardized by PAAS), samples from the Yubei 5 well were basically middle-coarse dolomite, while the samples from the Yubei 7 well were dominated by silt-fine dolomite.The REE patterns of these 2 types of samples clearly differ from one another. For middle-coarse dolomite, the associated REE patterns do not correspond well with each other, indicating that these samples may have been affected by different fluid resources. On the contrary, the REE patterns of the siltfine dolomite samples are consistent with each other, suggesting a unified source of diagenetic fluid.

$\mathrm{The}(\mathrm{La} / \mathrm{Yb})_{\text {PAAS }}$ ratios ranged from $0.42-1.44$, with an average of 1.09. Previous research has suggested that in hydrothermal fluid $(\mathrm{La} /$ Yb) PAAS $>1$, and when original marine stratigraphic water mixed with hydrothermal fluid, $(\mathrm{La} / \mathrm{Yb})_{\mathrm{PAAS}}<1$ (Sugitani, 1992). Thus, we concluded that the middle-coarse dolomite that formed in the deep part of the Penglaiba Formation was affected both by marine stratigraphic water and hydrothermal fluid, which is consistent with the ${ }^{87} \mathrm{Sr}^{86} \mathrm{~S}$ values.

Abnormal levels of $\mathrm{Ce}$ and Eu during diagenesis are related to the temperature and redox of the diagenetic fluid (Zheng et al., 1997; Zheng et al., 2008). A positive $\mathrm{Ce}$ anomaly indicates a reduction condition in the overlying water, while a negative value suggests an oxidation environment. In high temperature conditions, Eu is characterized by a positive anomaly, similar to that found in a reduction environment (Frimmel, 2009; Hu et al., 2011). $\delta$ Eu values within the dolomite samples from the southwest Tarim Basin ranged from 0.64-2.93 and most samples exhibited negative anomalies that gradually decreased with increasing depth. $\delta$ Ce varied from $0.56-0.88$, with an average value of 0.86 . As depth increased, the degree of the negative $\mathrm{Ce}$ anomaly decreased, and values of $\delta \mathrm{Ce} / \delta \mathrm{Eu}$ gradually increased from $<1$ to $>1$.

The results show that the $\delta \mathrm{Eu}$ values of samples from $6740.1 \mathrm{~m}$, $6743.27 \mathrm{~m}, 6744.1 \mathrm{~m}$, and $6839.9 \mathrm{~m}$ in the Yubei 5 well were positive anomalies, ranging from 1.29-2.93. Generally, a positive anomaly of a $\delta$ Eu value suggests a reductive or high temperature environment. It is uncommon, however, for $\mathrm{Eu}^{2+}$ to occur in a normal temperature environment. The condition for the presence of $\mathrm{Eu}^{2+}$ is very rigorous,

Table 4. REE characteristics of Yubei 5 well

\begin{tabular}{|c|c|c|c|c|c|c|c|}
\hline Well & Depth(m) & 6740.1 & 6743.27 & 6744.1 & 6839.9 & 6841.82 & 6842.1 \\
\hline \multirow{23}{*}{ Yubei 5} & $\mathrm{La}(\mu \mathrm{g} / \mathrm{g})$ & 0.017 & 0.006 & 0.01 & 0.013 & 0.02 & 0.015 \\
\hline & $\mathrm{Ce}(\mu \mathrm{g} / \mathrm{g})$ & 0.015 & 0.006 & 0.008 & 0.013 & 0.02 & 0.015 \\
\hline & $\operatorname{Pr}(\mu \mathrm{g} / \mathrm{g})$ & 0.024 & 0.016 & 0.017 & 0.02 & 0.027 & 0.023 \\
\hline & $\mathrm{Nd}(\mu \mathrm{g} / \mathrm{g})$ & 0.017 & 0.008 & 0.009 & 0.016 & 0.023 & 0.019 \\
\hline & $\mathrm{Sm}(\mu \mathrm{g} / \mathrm{g})$ & 0.031 & 0.022 & 0.023 & 0.026 & 0.035 & 0.032 \\
\hline & $\operatorname{Eu}(\mu \mathrm{g} / \mathrm{g})$ & 0.055 & 0.027 & 0.031 & 0.028 & 0.029 & 0.027 \\
\hline & $\mathrm{Gd}(\mu \mathrm{g} / \mathrm{g})$ & 0.018 & 0.004 & 0.005 & 0.017 & 0.03 & 0.024 \\
\hline & $\mathrm{Tb}(\mu \mathrm{g} / \mathrm{g})$ & 0.037 & 0.028 & 0.028 & 0.012 & 0.026 & 0.018 \\
\hline & $\mathrm{Dy}(\mu \mathrm{g} / \mathrm{g})$ & 0.022 & 0.014 & 0.014 & 0.012 & 0.023 & 0.021 \\
\hline & $\mathrm{Ho}(\mu \mathrm{g} / \mathrm{g})$ & 0.025 & 0.019 & 0.017 & 0.009 & 0.019 & 0.015 \\
\hline & $\operatorname{Er}(\mu \mathrm{g} / \mathrm{g})$ & 0.019 & 0.013 & 0.01 & 0.01 & 0.02 & 0.019 \\
\hline & $\operatorname{Tm}(\mu \mathrm{g} / \mathrm{g})$ & 0.051 & 0.047 & 0.043 & 0.1 & 0.111 & 0.107 \\
\hline & $\mathrm{Yb}(\mu \mathrm{g} / \mathrm{g})$ & 0.02 & 0.015 & 0.011 & 0.01 & 0.02 & 0.019 \\
\hline & $\mathrm{Lu}(\mu \mathrm{g} / \mathrm{g})$ & 0.053 & 0.05 & 0.046 & 0.009 & 0.017 & 0.017 \\
\hline & $\operatorname{Th}(\mu \mathrm{g} / \mathrm{g})$ & 0.312 & 0.132 & 0.099 & 0.206 & 0.409 & 0.442 \\
\hline & $\operatorname{Sr}(\mu \mathrm{g} / \mathrm{g})$ & 53.512 & 22.154 & 124.006 & 78.985 & 65.453 & 50.922 \\
\hline & $\mathrm{Ba}(\mu \mathrm{g} / \mathrm{g})$ & 107.716 & 14.163 & 28.374 & 85.804 & 48.965 & 74.068 \\
\hline & $\mathrm{La} / \mathrm{Yb}$ & 0.459 & 0.214 & 0.357 & 1.083 & 0.769 & 0.833 \\
\hline & $\delta \mathrm{Ce}$ & 0.754 & 0.559 & 0.615 & 0.767 & 0.831 & 0.809 \\
\hline & $\delta \mathrm{Eu}$ & 2.321 & 2.927 & 2.803 & 1.289 & 0.889 & 0.975 \\
\hline & $\delta \mathrm{Ce} / \delta \mathrm{Eu}$ & 0.325 & 0.191 & 0.219 & 0.595 & 0.934 & 0.83 \\
\hline & $\sum \mathrm{REE}$ & 3.243 & 1.465 & 1.881 & 2.637 & 4 & 3.169 \\
\hline & $\mathrm{Sr} / \mathrm{Ba}$ & 0.497 & 1.564 & 4.37 & 0.921 & 1.337 & 0.688 \\
\hline
\end{tabular}


Table 5. REE characteristics of Yubei 7 well

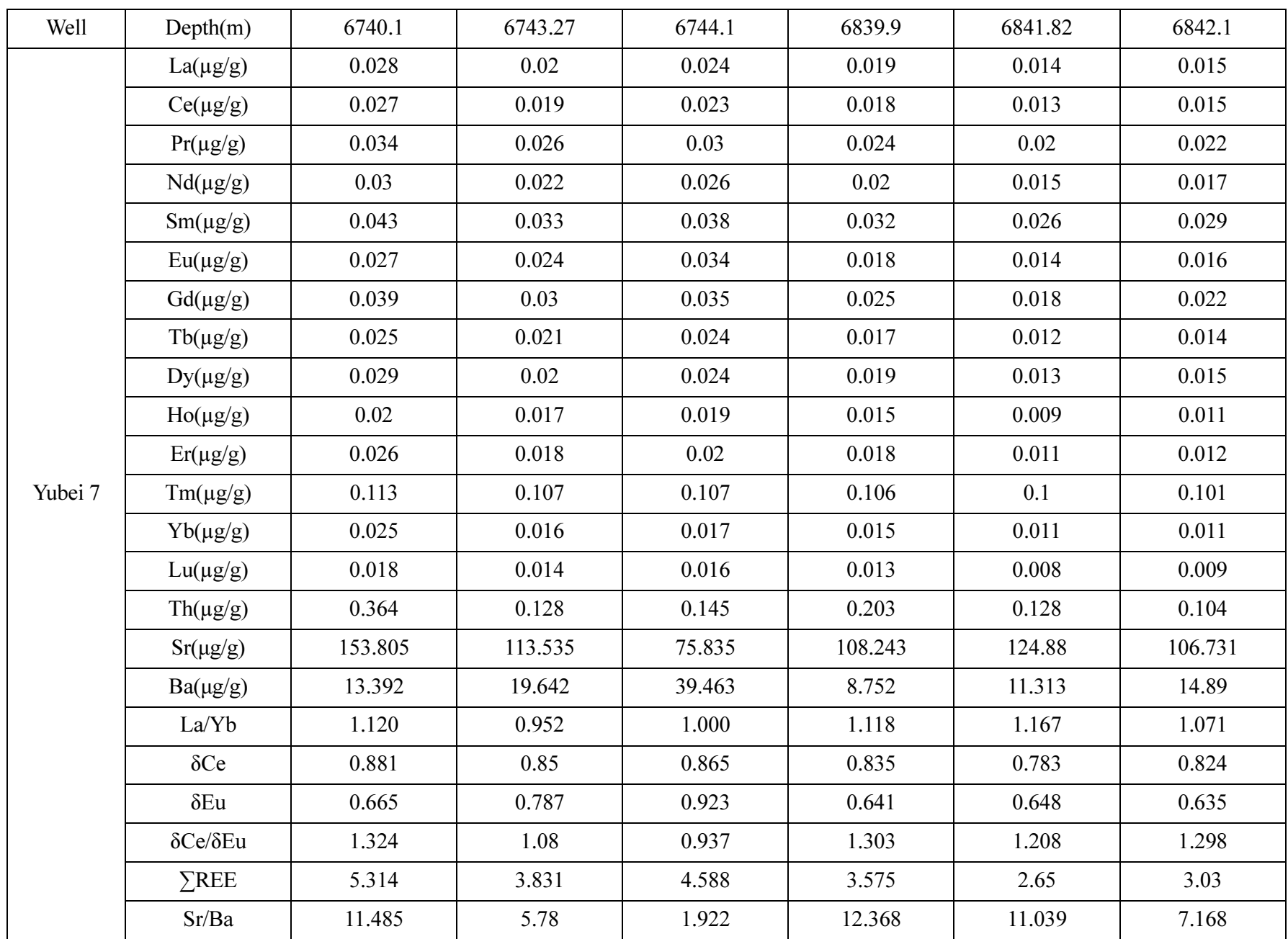

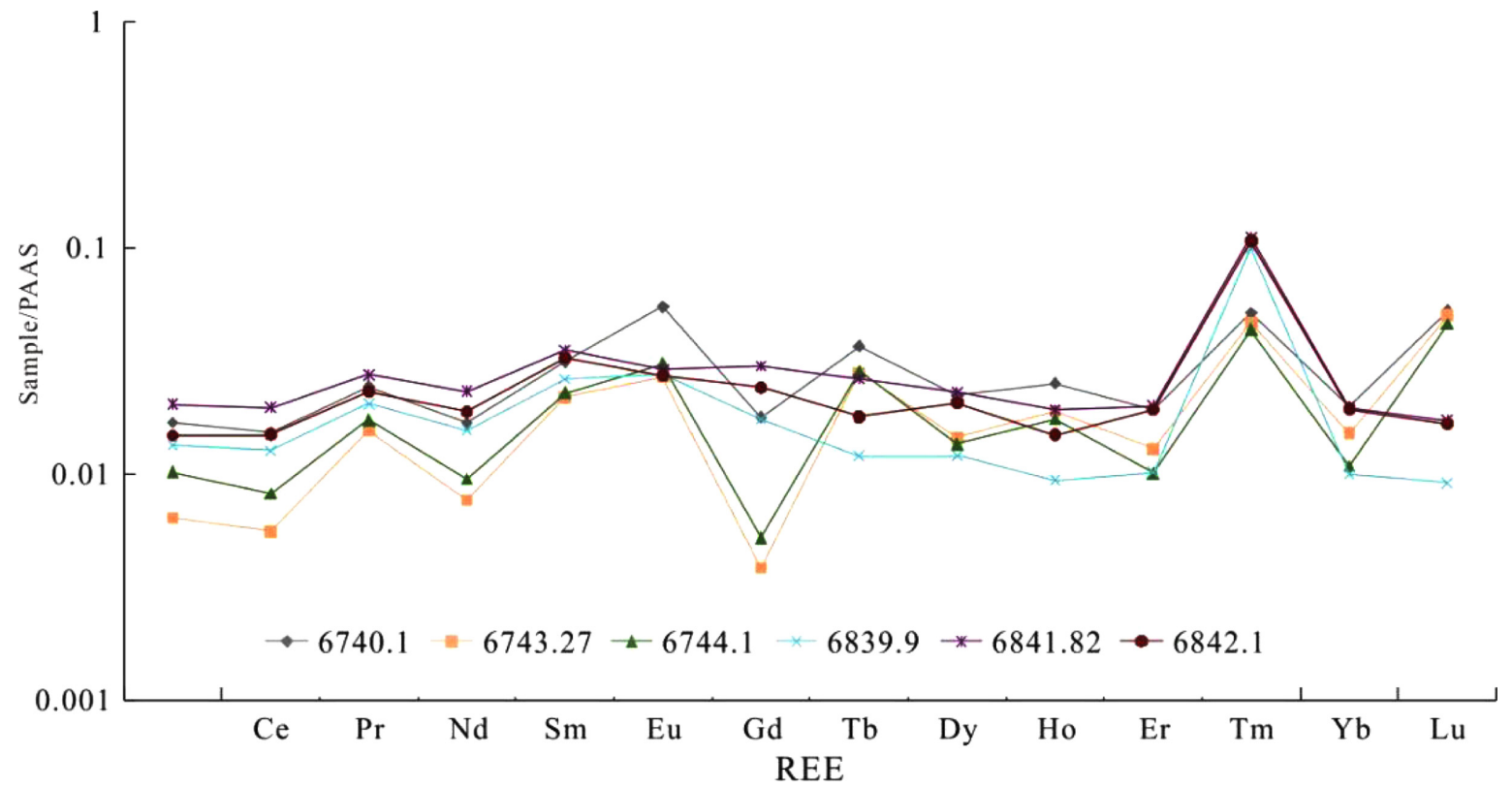

Figure 6. PAAS-normalized REE distribution patterns of the Penglaiba Formation in the Yubei 5 well.

requiring both reductive and alkaline conditions. Also, when the temperature is high, $\mathrm{Eu}^{2+}$ is stable and enters into the lattice, resulting in Eu enrichment (Sverjensky, 1984). In the southwest Tarim Basin, quartz can be found in the drill core and thin sections, indicating that the diagenetic fluid was acidic. Therefore, the positive anomaly of Eu in this study was caused by hydrothermal fluid. 


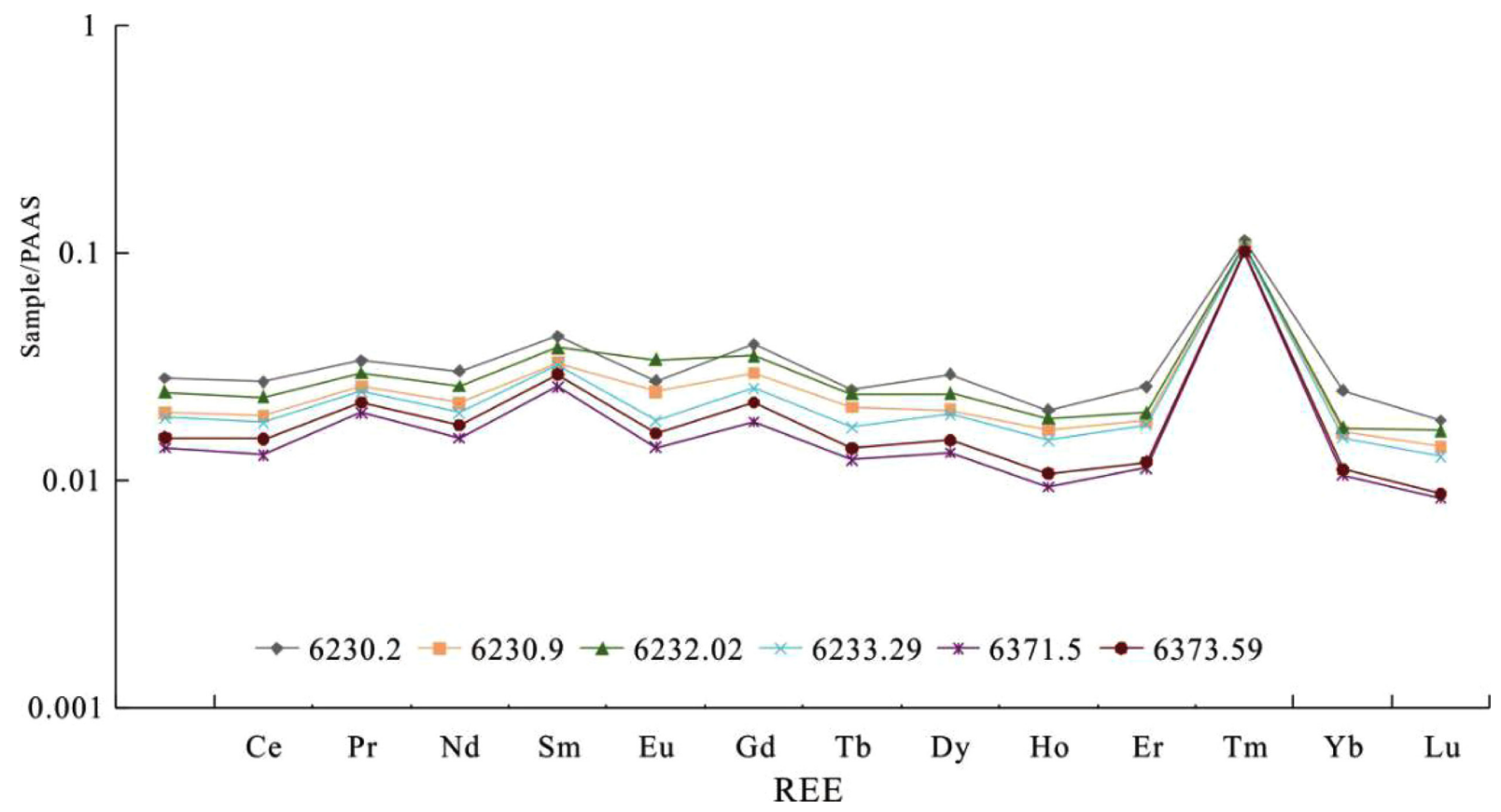

Figure 7. PAAS-normalized REE distribution patterns of the Penglaiba Formation in the Yubei 7 well.

Another 8 samples exhibited negative anomalies of $\delta \mathrm{Eu}$ and $\delta \mathrm{Ce}$, and $\delta \mathrm{Ce}$ values between $0.56-0.88$. $\delta \mathrm{Ce}$ values are closely related to transgression and regression. During the Penglaiba period, sea level eustacy occurred frequently, resulting in carbonate platform exposure and periodic denuding, as well as atmospheric fresh water leaching. And due to the relatively high oxygen content, rock-water interaction occurred in an oxidation environment, and led to a negative Ce anomaly (Hu et al., 2010).

\section{Fluid Inclusion}

Fluid inclusion samples from matrix dolomite, as well as calcite filled in dissolved pores and fractures from the Yubei 5 and Yubei 7 wells, were selected for homogenization temperature and freezing point testing (Table 6). The shapes of the inclusions in study area included cir- cles, rectangles, squares, ovals, and polygons, as well as long and irregular forms (Fig. 8).

By measuring the homogenization temperatures of the inclusions, fluid properties can be characterized objectively and effectively. The range of the temperature was from $100-210{ }^{\circ} \mathrm{C}$, exhibiting a multiphase character. The frequency distribution histogram shows there were 3 peak values, one between $140-150^{\circ} \mathrm{C}$, and two others from $100-110{ }^{\circ} \mathrm{C}$ and $160-170^{\circ} \mathrm{C}$ (Fig. 9), suggesting there were at least three main episodes of fluid activity.

The homogenization temperatures of inclusions from the samples in the study area were all relatively high, indicating that dolomite experienced a deep burial environment with a high temperature.

The characteristics of the homogeneous and freezing point temperatures of fluid inclusion in matrix dolomite, fractures, and hole fillings in the southwest Tarim Basin are shown in Figs. 9 and 10. The
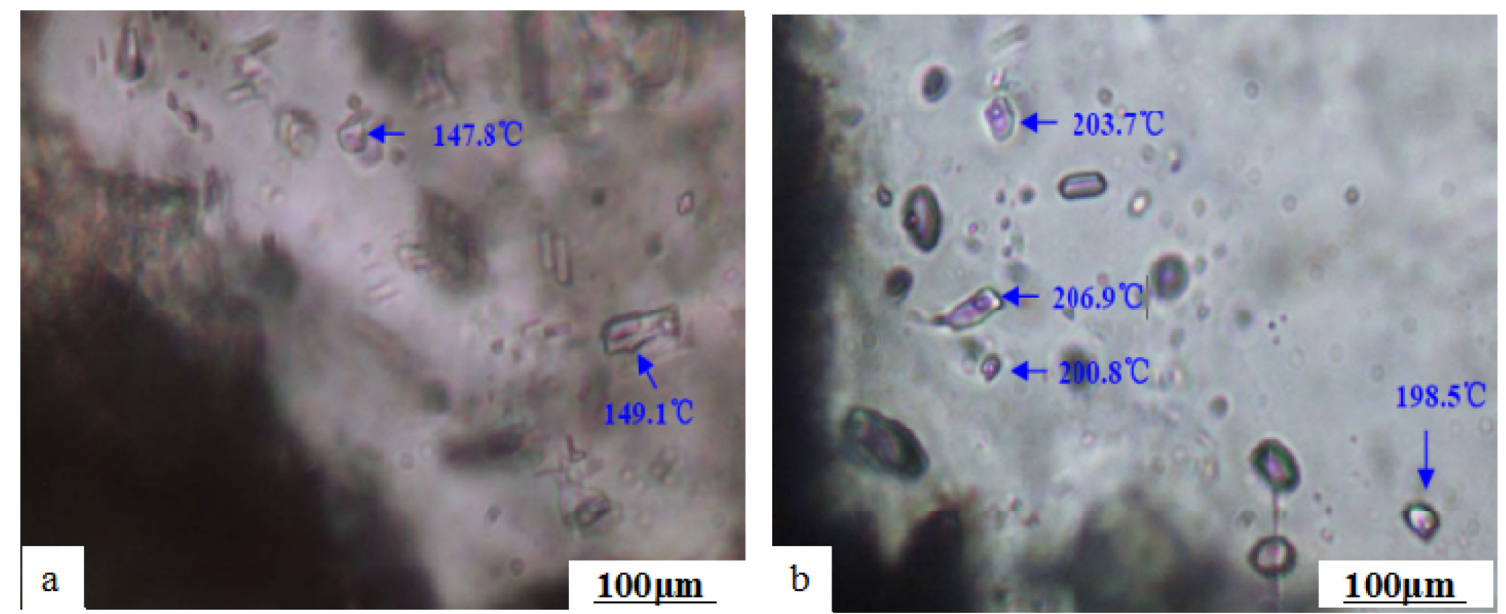

Figure 8. Inclusion characteristics of carbonate in the southwest Tarim Basin (a: Yubei 5 well, Yingshan Formation, 5998.29 m; b: Yubei 7well, Penglaiba Formation, $6382.3 \mathrm{~m}$ ). 
Table 6. Homogenization temperature in study area

\begin{tabular}{|c|c|c|c|c|c|c|c|c|}
\hline Wells & Formations & $\operatorname{Depth}(\mathrm{m})$ & mineral & $\begin{array}{l}\text { Size } \\
(\mu \mathrm{m})\end{array}$ & $\begin{array}{l}\text { Gas liquid } \\
\text { ratio(\%) }\end{array}$ & $\begin{array}{l}\text { Homogenization } \\
\text { temperature }\left(\mathrm{Th} /{ }^{\circ} \mathrm{C}\right)\end{array}$ & $\begin{array}{l}\text { Freezin point tem- } \\
\text { perature }\left(\mathrm{Tm} /{ }^{\circ} \mathrm{C}\right)\end{array}$ & $\begin{array}{c}\text { Salinity } \\
\text { (wt\% } \% \mathrm{NaCl} \text { ) }\end{array}$ \\
\hline Yubei 5 & Yingshan & 6605.84 & matrix & 4 & 2 & 101.7 & -18.7 & 21.5 \\
\hline Yubei 5 & Yingshan & 6605.84 & matrix & 3 & 4 & 106.4 & -16.2 & 19.6 \\
\hline Yubei 5 & Yingshan & 6605.84 & matrix & 3 & 2 & 137.3 & -24.2 & 25.1 \\
\hline Yubei 5 & Yingshan & 6605.84 & matrix & 4 & 4 & 140.9 & -22.4 & 24 \\
\hline Yubei 5 & Yingshan & 6605.84 & matrix & 5 & 3 & 141.8 & -26.4 & 26.4 \\
\hline Yubei 5 & Yingshan & 6605.84 & matrix & 4 & 5 & 143.5 & -21.7 & 23.5 \\
\hline Yubei 5 & Yingshan & 6605.84 & matrix & 3 & 3 & 144.2 & -24.6 & 25.3 \\
\hline Yubei 5 & Yingshan & 6605.84 & matrix & 6 & 4 & 145.8 & -20.7 & 22.8 \\
\hline Yubei 5 & Yingshan & 6605.84 & matrix & 6 & 5 & 147.2 & -21.6 & 23.4 \\
\hline Yubei 5 & Yingshan & 6605.84 & matrix & 3 & 4 & 149.6 & -23.8 & 24.8 \\
\hline Yubei 5 & Yingshan & 6605.84 & matrix & 5 & 9 & 161.3 & -12.5 & 16.4 \\
\hline Yubei 5 & Yingshan & 6605.84 & matrix & 4 & 3 & 162.7 & -10.8 & 14.8 \\
\hline Yubei 5 & Yingshan & 6605.84 & matrix & 6 & 5 & 165.6 & -13.3 & 17.2 \\
\hline Yubei 5 & Yingshan & 6605.84 & matrix & 5 & 3 & 167.1 & -9.2 & 13.1 \\
\hline Yubei 5 & Penglaiba & 6742.44 & matrix & 5 & 2 & 138.2 & -28.1 & 27.5 \\
\hline Yubei 5 & Penglaiba & 6742.44 & matrix & 3 & 3 & 141.3 & -25.3 & 25.8 \\
\hline Yubei 5 & Penglaiba & 6742.44 & matrix & 5 & 3 & 142.7 & -20.6 & 22.8 \\
\hline Yubei 5 & Penglaiba & 6742.44 & matrix & 6 & 3 & 145.6 & -22.4 & 24 \\
\hline Yubei 5 & Penglaiba & 6742.44 & matrix & 6 & 4 & 146.7 & -22.4 & 24 \\
\hline Yubei 5 & Penglaiba & 6742.44 & matrix & 4 & 4 & 148.1 & -26.5 & 26.5 \\
\hline Yubei 5 & Penglaiba & 6742.44 & matrix & 6 & 2 & 163.4 & -9.2 & 13.1 \\
\hline Yubei 5 & Penglaiba & 6742.44 & matrix & 5 & 4 & 165.7 & -5.7 & 8.8 \\
\hline Yubei 5 & Penglaiba & 6742.44 & matrix & 4 & 5 & 166.5 & -10.3 & 14.3 \\
\hline Yubei 5 & Penglaiba & 6742.44 & matrix & 6 & 5 & 169.1 & -11.3 & 15.3 \\
\hline Yubei 5 & Penglaiba & 6742.44 & matrix & 3 & 4 & 171.8 & -7.3 & 10.9 \\
\hline Yubei 5 & Penglaiba & 6839.91 & matrix & 5 & 5 & 125.2 & -12.8 & 16.7 \\
\hline Yubei 5 & Penglaiba & 6839.91 & matrix & 3 & 2 & 127.8 & -15.7 & 19.2 \\
\hline Yubei 5 & Penglaiba & 6839.91 & matrix & 5 & 4 & 184.6 & -16.3 & 19.7 \\
\hline Yubei 5 & Penglaiba & 6839.91 & matrix & 3 & 8 & 187.5 & -14.4 & 18.1 \\
\hline Yubei 5 & Penglaiba & 6839.91 & matrix & 3 & 2 & 190.7 & -9.4 & 13.3 \\
\hline Yubei 5 & Penglaiba & 6839.91 & matrix & 4 & 5 & 193.4 & -11.8 & 15.8 \\
\hline Yubei 5 & Penglaiba & 6841.92 & matrix & 4 & 5 & 107.4 & -13.8 & 17.6 \\
\hline Yubei 5 & Penglaiba & 6841.92 & matrix & 4 & 3 & 109.6 & -11.4 & 15.4 \\
\hline Yubei 5 & Penglaiba & 6841.92 & matrix & 5 & 4 & 137.9 & -27.1 & 26.9 \\
\hline Yubei 5 & Penglaiba & 6841.92 & matrix & 2 & 3 & 142.6 & -24.4 & 25.2 \\
\hline Yubei 5 & Penglaiba & 6841.92 & matrix & 3 & 2 & 144.7 & -28.1 & 27.5 \\
\hline Yubei 5 & Penglaiba & 6841.92 & matrix & 5 & 4 & 145.2 & -26.5 & 26.5 \\
\hline Yubei 5 & Penglaiba & 6841.92 & matrix & 6 & 5 & 146.5 & -27.9 & 27.4 \\
\hline Yubei 5 & Penglaiba & 6841.92 & matrix & 8 & 5 & 148.3 & -25.2 & 25.7 \\
\hline Yubei 5 & Penglaiba & 6841.92 & matrix & 5 & 4 & 164.4 & -17.4 & 20.5 \\
\hline Yubei 5 & Penglaiba & 6841.92 & matrix & 4 & 3 & 166.3 & -18.8 & 21.5 \\
\hline Yubei 5 & Penglaiba & 6841.92 & matrix & 4 & 6 & 168.1 & -17.6 & 20.7 \\
\hline Yubei 5 & Penglaiba & 6841.92 & matrix & 6 & 5 & 169.2 & -15.2 & 18.8 \\
\hline Yubei 5 & Penglaiba & 6841.92 & matrix & 5 & 4 & 169.7 & -19.5 & 22 \\
\hline
\end{tabular}


Table 6. Continued

\begin{tabular}{|c|c|c|c|c|c|c|c|c|}
\hline Wells & Formations & $\operatorname{Depth}(\mathrm{m})$ & mineral & $\begin{array}{l}\text { Size } \\
(\mu \mathrm{m})\end{array}$ & $\begin{array}{l}\text { Gas liquid } \\
\text { ratio( }(\%)\end{array}$ & $\begin{array}{c}\text { Homogenization } \\
\text { temperature }\left(\mathrm{Th} /{ }^{\circ} \mathrm{C}\right)\end{array}$ & \begin{tabular}{|l|} 
Freezin point tem- \\
perature $\left(\mathrm{Tm} /{ }^{\circ} \mathrm{C}\right)$
\end{tabular} & $\begin{array}{c}\text { Salinity } \\
\text { (wt\% } \% \mathrm{NaCl} \text { ) }\end{array}$ \\
\hline Yubei 5 & Penglaiba & 6841.92 & matrix & 5 & 4 & 172.1 & -17.3 & 20.4 \\
\hline Yubei 5 & Penglaiba & 6842.73 & matrix & 3 & 9 & 104.7 & -12.6 & 16.5 \\
\hline Yubei 5 & Penglaiba & 6842.73 & matrix & 4 & 4 & 105.2 & -15.3 & 18.9 \\
\hline Yubei 5 & Penglaiba & 6842.73 & matrix & 5 & 7 & 108.3 & -14.8 & 18.5 \\
\hline Yubei 5 & Penglaiba & 6842.73 & matrix & 5 & 6 & 109.4 & -14.7 & 18.4 \\
\hline Yubei 5 & Penglaiba & 6842.73 & matrix & 3 & 2 & 135.6 & -21.2 & 23.2 \\
\hline Yubei 5 & Penglaiba & 6842.73 & matrix & 6 & 5 & 141.2 & -25.1 & 25.6 \\
\hline Yubei 5 & Penglaiba & 6842.73 & matrix & 4 & 5 & 142.8 & -22.8 & 24.2 \\
\hline Yubei 5 & Penglaiba & 6842.73 & matrix & 4 & 5 & 146.2 & -21.4 & 23.3 \\
\hline Yubei 5 & Penglaiba & 6842.73 & matrix & 3 & 3 & 149.5 & -26.5 & 26.5 \\
\hline Yubei 5 & Penglaiba & 6842.73 & matrix & 4 & 5 & 168.6 & -31.4 & 29.6 \\
\hline Yubei 5 & Penglaiba & 6842.73 & matrix & 4 & 7 & 170.3 & -27.3 & 27 \\
\hline Yubei 5 & Penglaiba & 6842.73 & matrix & 3 & 4 & 171.5 & -30.7 & 29.1 \\
\hline Yubei 5 & Penglaiba & 6842.73 & matrix & 4 & 6 & 173.9 & -29.5 & 28.3 \\
\hline Yubei 5 & Penglaiba & 6842.73 & matrix & 3 & 5 & 175.4 & -32.6 & 30.4 \\
\hline Yubei 5 & Penglaiba & 6233.44 & matrix & 4 & 5 & 102.7 & -5.2 & 8.1 \\
\hline Yubei 5 & Penglaiba & 6233.44 & matrix & 3 & 2 & 104.6 & -6.7 & 10.1 \\
\hline Yubei 5 & Penglaiba & 6233.44 & matrix & 5 & 4 & 140.1 & -15.3 & 18.9 \\
\hline Yubei 5 & Penglaiba & 6233.44 & matrix & 4 & 2 & 141.7 & -19.2 & 21.8 \\
\hline Yubei 5 & Penglaiba & 6233.44 & matrix & 5 & 8 & 142.5 & -16.7 & 20 \\
\hline Yubei 5 & Penglaiba & 6233.44 & matrix & 3 & 4 & 149.2 & -21.4 & 23.3 \\
\hline Yubei 5 & Penglaiba & 6233.44 & matrix & 2 & 3 & 163.4 & -12.6 & 16.5 \\
\hline Yubei 5 & Penglaiba & 6233.44 & matrix & 3 & 5 & 165.4 & -7.5 & 11.1 \\
\hline Yubei 5 & Penglaiba & 6233.44 & matrix & 3 & 5 & 166.3 & -10.8 & 14.8 \\
\hline Yubei 5 & Penglaiba & 6233.44 & matrix & 3 & 2 & 168.3 & -9.1 & 13 \\
\hline Yubei 5 & Penglaiba & 6233.44 & matrix & 4 & 3 & 169.8 & -8.6 & 12.4 \\
\hline Yubei 5 & Penglaiba & 6233.44 & matrix & 4 & 4 & 172.6 & -8.8 & 12.6 \\
\hline Yubei 5 & Yingshan & 5998.29 & calcite filled in pores & 10 & 8 & 103.5 & -8.5 & 12.3 \\
\hline Yubei 5 & Yingshan & 5998.29 & calcite filled in pores & 4 & 7 & 105.4 & -11.8 & 15.8 \\
\hline Yubei 5 & Yingshan & 5998.29 & calcite filled in pores & 4 & 3 & 107.3 & -6.4 & 9.7 \\
\hline Yubei 5 & Yingshan & 5998.29 & calcite filled in pores & 3 & 4 & 107.9 & -12.3 & 16.2 \\
\hline Yubei 5 & Yingshan & 5998.29 & calcite filled in pores & 5 & 4 & 108.8 & -9.6 & 13.5 \\
\hline Yubei 5 & Yingshan & 5998.29 & calcite filled in pores & 3 & 5 & 111.2 & -9.1 & 13 \\
\hline Yubei 5 & Yingshan & 5998.29 & calcite filled in pores & 5 & 7 & 188.6 & -15.9 & 19.4 \\
\hline Yubei 5 & Yingshan & 5998.29 & calcite filled in pores & 4 & 3 & 189.2 & -18.2 & 21.1 \\
\hline Yubei 5 & Penglaiba & 6744.17 & calcite filled in pores & 5 & 5 & 102.6 & -15.4 & 19 \\
\hline Yubei 5 & Penglaiba & 6744.17 & calcite filled in pores & 3 & 2 & 108.7 & -11.2 & 15.2 \\
\hline Yubei 5 & Penglaiba & 6744.17 & calcite filled in pores & 5 & 7 & 121.7 & -22.4 & 24 \\
\hline Yubei 5 & Penglaiba & 6744.17 & calcite filled in pores & 3 & 5 & 125.3 & -21.6 & 23.4 \\
\hline Yubei 5 & Penglaiba & 6744.17 & calcite filled in pores & 3 & 4 & 126.4 & -26.3 & 26.4 \\
\hline Yubei 5 & Penglaiba & 6744.17 & calcite filled in pores & 4 & 6 & 127.2 & -18.5 & 21.3 \\
\hline Yubei 5 & Penglaiba & 6744.17 & calcite filled in pores & 3 & 4 & 130.8 & -23.8 & 24.8 \\
\hline Yubei 5 & Penglaiba & 6744.17 & calcite filled in pores & 3 & 2 & 141.8 & -23.9 & 24.9 \\
\hline Yubei 5 & Penglaiba & 6744.17 & calcite filled in pores & 5 & 4 & 142.8 & -25.9 & 26.1 \\
\hline Yubei 5 & Penglaiba & 6744.17 & calcite filled in pores & 3 & 6 & 145.2 & -25.4 & 25.8 \\
\hline Yubei 5 & Penglaiba & 6744.17 & calcite filled in pores & 4 & 6 & 147.3 & -28.7 & 27.8 \\
\hline
\end{tabular}


Table 6. Continued

\begin{tabular}{|c|c|c|c|c|c|c|c|c|}
\hline Wells & Formations & $\operatorname{Depth}(\mathrm{m})$ & mineral & $\begin{array}{l}\text { Size } \\
(\mu \mathrm{m})\end{array}$ & $\begin{array}{l}\text { Gas liquid } \\
\text { ratio(\%) }\end{array}$ & $\begin{array}{c}\text { Homogenization } \\
\text { temperature }\left(\mathrm{Th} /{ }^{\circ} \mathrm{C}\right)\end{array}$ & $\begin{array}{l}\text { Freezin point tem- } \\
\text { perature }\left(\mathrm{Tm} /{ }^{\circ} \mathrm{C}\right)\end{array}$ & $\begin{array}{c}\text { Salinity } \\
(\mathrm{wt} \% \mathrm{NaCl})\end{array}$ \\
\hline Yubei 5 & Penglaiba & 6744.17 & calcite filled in pores & 4 & 3 & 150.7 & -24.6 & 25.3 \\
\hline Yubei 5 & Penglaiba & 6744.17 & calcite filled in pores & 3 & 2 & 162.9 & -8.5 & 12.3 \\
\hline Yubei 5 & Penglaiba & 6744.17 & calcite filled in pores & 6 & 4 & 166.4 & -10.7 & 14.7 \\
\hline Yubei 5 & Penglaiba & 6744.17 & calcite filled in pores & 4 & 2 & 167.8 & -5.8 & 8.9 \\
\hline Yubei 5 & Penglaiba & 6744.17 & calcite filled in pores & 5 & 4 & 169.1 & -7.3 & 10.9 \\
\hline Yubei 7 & Penglaiba & 6367.63 & calcite filled in pores & 6 & 7 & 103.4 & -8.8 & 12.6 \\
\hline Yubei 7 & Penglaiba & 6367.63 & calcite filled in pores & 4 & 5 & 103.7 & -7.1 & 10.6 \\
\hline Yubei 7 & Penglaiba & 6367.63 & calcite filled in pores & 5 & 4 & 106.2 & -6.5 & 9.9 \\
\hline Yubei 7 & Penglaiba & 6367.63 & calcite filled in pores & 4 & 5 & 107.8 & -5.2 & 8.1 \\
\hline Yubei 7 & Penglaiba & 6367.63 & calcite filled in pores & 6 & 7 & 143.3 & -15.6 & 19.1 \\
\hline Yubei 7 & Penglaiba & 6367.63 & calcite filled in pores & 5 & 4 & 146.1 & -18.4 & 21.3 \\
\hline Yubei 7 & Penglaiba & 6367.63 & calcite filled in pores & 5 & 9 & 148.7 & -12.9 & 16.8 \\
\hline Yubei 7 & Penglaiba & 6367.63 & calcite filled in pores & 4 & 8 & 198.5 & -6.4 & 9.7 \\
\hline Yubei 7 & Penglaiba & 6367.63 & calcite filled in pores & 8 & 7 & 200.8 & -8.2 & 11.9 \\
\hline Yubei 7 & Penglaiba & 6367.63 & calcite filled in pores & 6 & 3 & 202.3 & -13.2 & 17.1 \\
\hline Yubei 7 & Penglaiba & 6367.63 & calcite filled in pores & 6 & 6 & 202.3 & -13.2 & 17.1 \\
\hline Yubei 7 & Penglaiba & 6367.63 & calcite filled in pores & 8 & 4 & 206.9 & -11.5 & 15.5 \\
\hline Yubei 7 & Penglaiba & 6367.63 & calcite filled in pores & 5 & 5 & 207.7 & -9.1 & 13 \\
\hline Yubei 7 & Penglaiba & 6367.63 & calcite filled in pores & 4 & 6 & 208.4 & -11.6 & 15.6 \\
\hline Yubei 7 & Penglaiba & 6367.63 & calcite filled in pores & 6 & 5 & 210.2 & -8.4 & 12.2 \\
\hline Yubei 7 & Penglaiba & 6373.4 & calcite filled in pores & 6 & 4 & 101.7 & -13 & 16.9 \\
\hline Yubei 7 & Penglaiba & 6373.4 & calcite filled in pores & 5 & 4 & 107.3 & -8.4 & 12.2 \\
\hline Yubei 7 & Penglaiba & 6373.4 & calcite filled in pores & 5 & 2 & 108.2 & -15.7 & 19.2 \\
\hline Yubei 7 & Penglaiba & 6373.4 & calcite filled in pores & 4 & 3 & 108.6 & -8.6 & 12.4 \\
\hline Yubei 7 & Penglaiba & 6373.4 & calcite filled in pores & 5 & 3 & 109.6 & -7.8 & 11.5 \\
\hline Yubei 7 & Penglaiba & 6373.4 & calcite filled in pores & 6 & 4 & 110.2 & -10.4 & 14.4 \\
\hline Yubei 7 & Penglaiba & 6373.4 & calcite filled in pores & 4 & 4 & 112.7 & -5.9 & 9.1 \\
\hline Yubei 7 & Penglaiba & 6373.4 & calcite filled in pores & 3 & 3 & 140.3 & -20.7 & 22.8 \\
\hline Yubei 7 & Penglaiba & 6373.4 & calcite filled in pores & 7 & 4 & 143.2 & -12.5 & 16.4 \\
\hline Yubei 7 & Penglaiba & 6373.4 & calcite filled in pores & 5 & 6 & 146.1 & -15.5 & 19 \\
\hline Yubei 7 & Penglaiba & 6373.4 & calcite filled in pores & 5 & 3 & 146.7 & -18.3 & 21.2 \\
\hline Yubei 7 & Penglaiba & 6373.4 & calcite filled in pores & 4 & 3 & 163.1 & -12.4 & 16.3 \\
\hline Yubei 7 & Penglaiba & 6373.4 & calcite filled in pores & 6 & 4 & 164.8 & -11.8 & 15.8 \\
\hline Yubei 7 & Penglaiba & 6373.4 & calcite filled in pores & 6 & 5 & 165.4 & 10.2 & 14.1 \\
\hline Yubei 7 & Penglaiba & 6373.4 & calcite filled in pores & 3 & 3 & 166.5 & -9.8 & 13.7 \\
\hline Yubei 7 & Penglaiba & 6373.4 & calcite filled in pores & 4 & 6 & 167.8 & -9.4 & 13.3 \\
\hline Yubei 7 & Penglaiba & 6373.4 & calcite filled in pores & 6 & 5 & 168.4 & -13.7 & 17.5 \\
\hline Yubei 5 & Penglaiba & 6839.91 & calcite filled in fractures & 3 & 4 & 118.4 & -15.3 & 18.9 \\
\hline Yubei 5 & Penglaiba & 6839.91 & calcite filled in fractures & 4 & 4 & 123.5 & -16.5 & 19.8 \\
\hline Yubei 5 & Penglaiba & 6839.91 & calcite filled in fractures & 4 & 3 & 162.1 & -5.7 & 8.8 \\
\hline Yubei 5 & Penglaiba & 6839.91 & calcite filled in fractures & 4 & 6 & 162.8 & -8.1 & 11.8 \\
\hline Yubei 5 & Penglaiba & 6839.91 & calcite filled in fractures & 3 & 5 & 164.3 & -7.5 & 11.1 \\
\hline Yubei 5 & Penglaiba & 6839.91 & calcite filled in fractures & 10 & 5 & 166.5 & -10.1 & 14 \\
\hline Yubei 5 & Penglaiba & 6839.91 & calcite filled in fractures & 8 & 5 & 167.9 & -7.2 & 10.7 \\
\hline Yubei 5 & Penglaiba & 6839.91 & calcite filled in fractures & 4 & 5 & 168.2 & -5.8 & 8.9 \\
\hline Yubei 5 & Penglaiba & 6839.91 & calcite filled in fractures & 8 & 6 & 170.5 & -6.3 & 9.6 \\
\hline
\end{tabular}




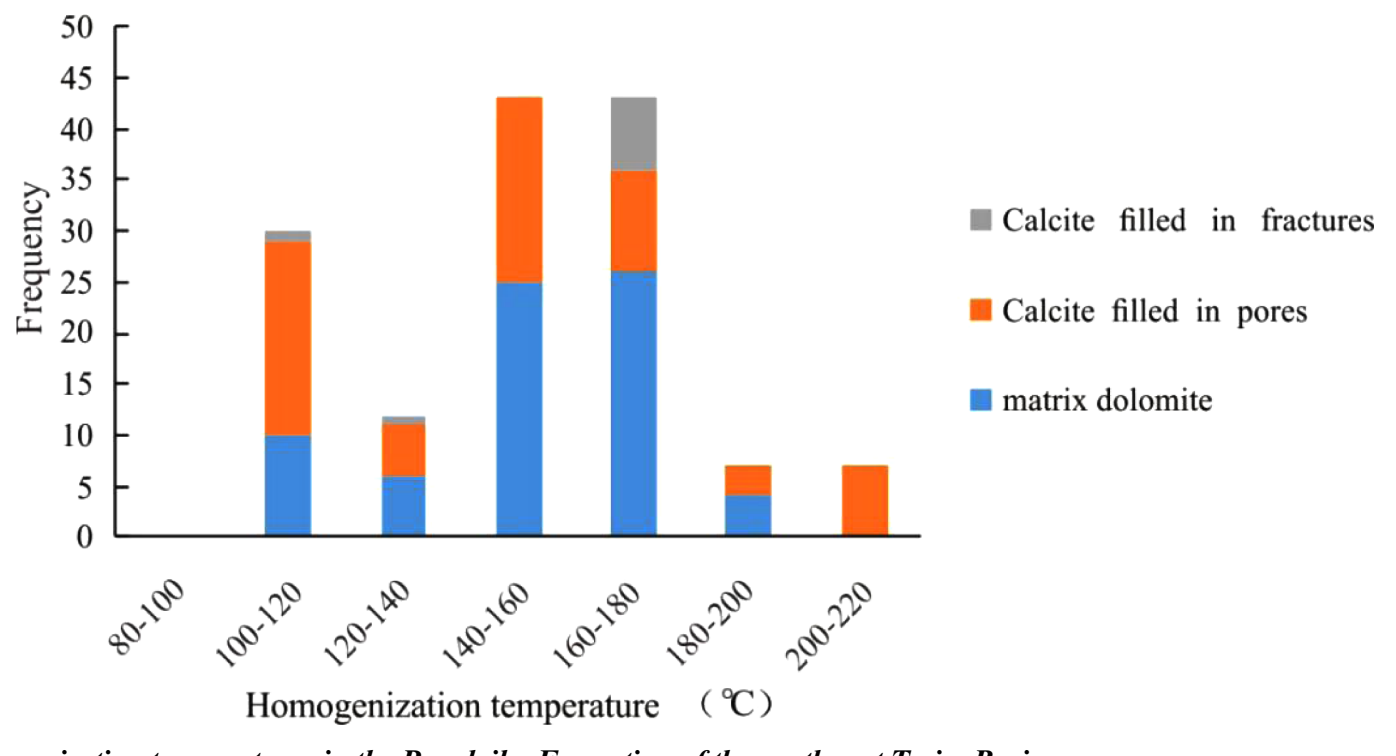

Figure 9. Homogenization temperatures in the Penglaiba Formation of the southwest Tarim Basin.

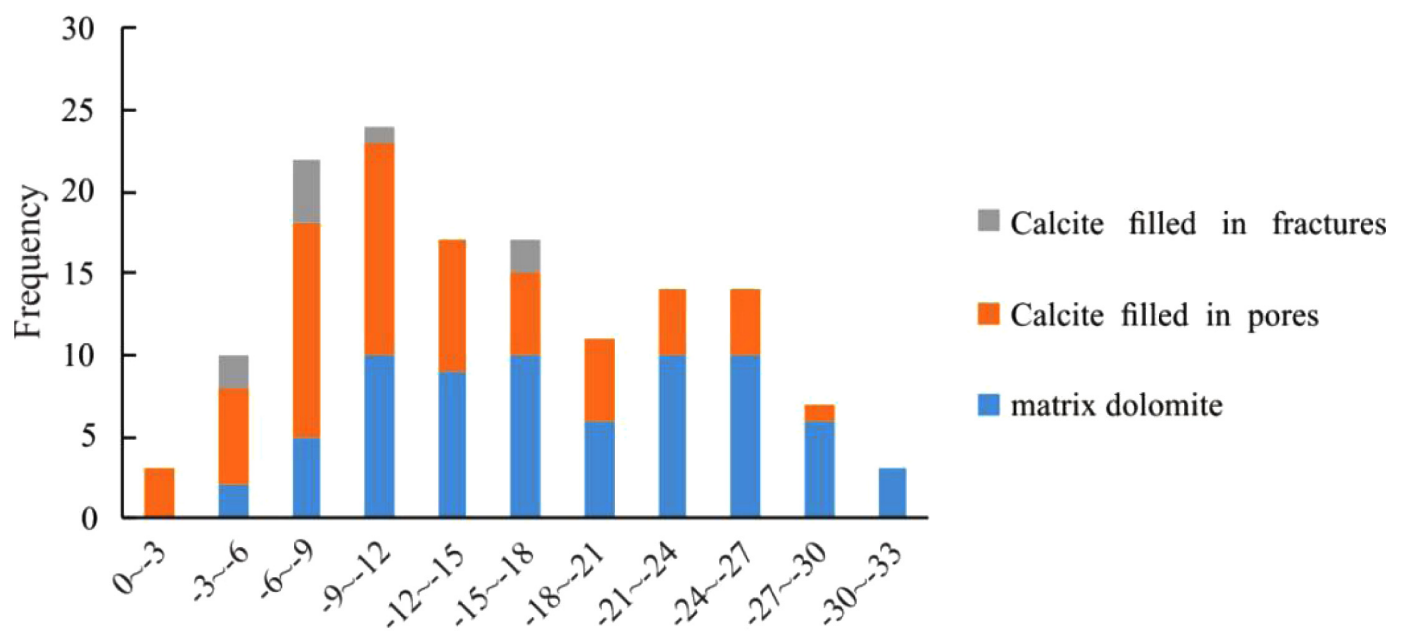

Freezing point $\left({ }^{\circ} \mathrm{C}\right)$

Figure 10. Freezing point temperatures in the Penglaiba Formation of the southwest Tarim Basin.

homogeneous temperature of fluid inclusion in matrix dolomite ranged between $101.7-193.4^{\circ} \mathrm{C}$, mainly distributed between $140-180^{\circ} \mathrm{C}$, with an average value of $149.3^{\circ} \mathrm{C}$. The freezing point temperature varied from -32.6 to $-5.2{ }^{\circ} \mathrm{C}$, concentrated between -9 to $-30{ }^{\circ} \mathrm{C}$. the corresponding salinity was between $8.1-30.4 \mathrm{wt} \% \mathrm{NaCl}_{\text {eqv }}$.

The homogeneous temperature of fluid inclusion within calcite which filled in dissolved pores varied from $101.7-210.2^{\circ} \mathrm{C}$, concentrated between $100-120^{\circ} \mathrm{C}$ and $140-220^{\circ} \mathrm{C}$. Homogeneous temperatures of this type of inclusion have a relatively wide range, indicating that it may form in a variety of diagenetic environments or diagenetic stages (Huang et al., 2014). Its freezing point temperature ranged from -28.7 to $10.2{ }^{\circ} \mathrm{C}$, with peak frequencies between -12 and $-6{ }^{\circ} \mathrm{C}$ (Fig. 10). Salinity was between $1.2-27.8 \mathrm{wt} \% \mathrm{NaCl}_{\text {eqv }}$.

The homogeneous temperature of the fluid inclusion within calcite which filled in fractures varied from $118.4-170.5^{\circ} \mathrm{C}$, concentrated between $160-180^{\circ} \mathrm{C}$, with a mean value of $153.9^{\circ} \mathrm{C}$. These temperature values are relatively high. Its freezing point temperature ranged from -16.5 to $-5.7^{\circ} \mathrm{C}$, with peak frequencies between -9 and $-6{ }^{\circ} \mathrm{C}$.
The corresponding salinity was between $8.8-19.8 \mathrm{wt} \% \mathrm{NaCl}_{\text {eqv }}$.

In the combined salinity and homogeneity temperature cross-plot (Fig. 11), three main stages of diagenetic fluid with one hydrothermal fluid can be recognized. The temperature of the first stage ranged from $100-110^{\circ} \mathrm{C}$, and the salinity varied from $8-2 \%$. The second stage temperature ranged between $120-150^{\circ} \mathrm{C}$, and the salinity was $16-$ $28 \%$. The temperature of the third stage was between $160-170{ }^{\circ} \mathrm{C}$, with corresponding salinity levels of $8-31 \%$, and the hydrothermal stage had temperatures between $180-210{ }^{\circ} \mathrm{C}$ with salinity values of $9-22 \%$.

\section{Hydrothermal Characteristics}

Hydrothermal fluids usually migrate along faults and associated secondary fractures, accompanied by some typical hydrothermal mineral assemblages (Jin et al., 2006). Geochemical and petrologic characteristics indicate a hydrothermal dolomitization in the southwest Tarim Basin, which has been rarely mentioned previously. This section will focus on the hydrothermal characteristics. 


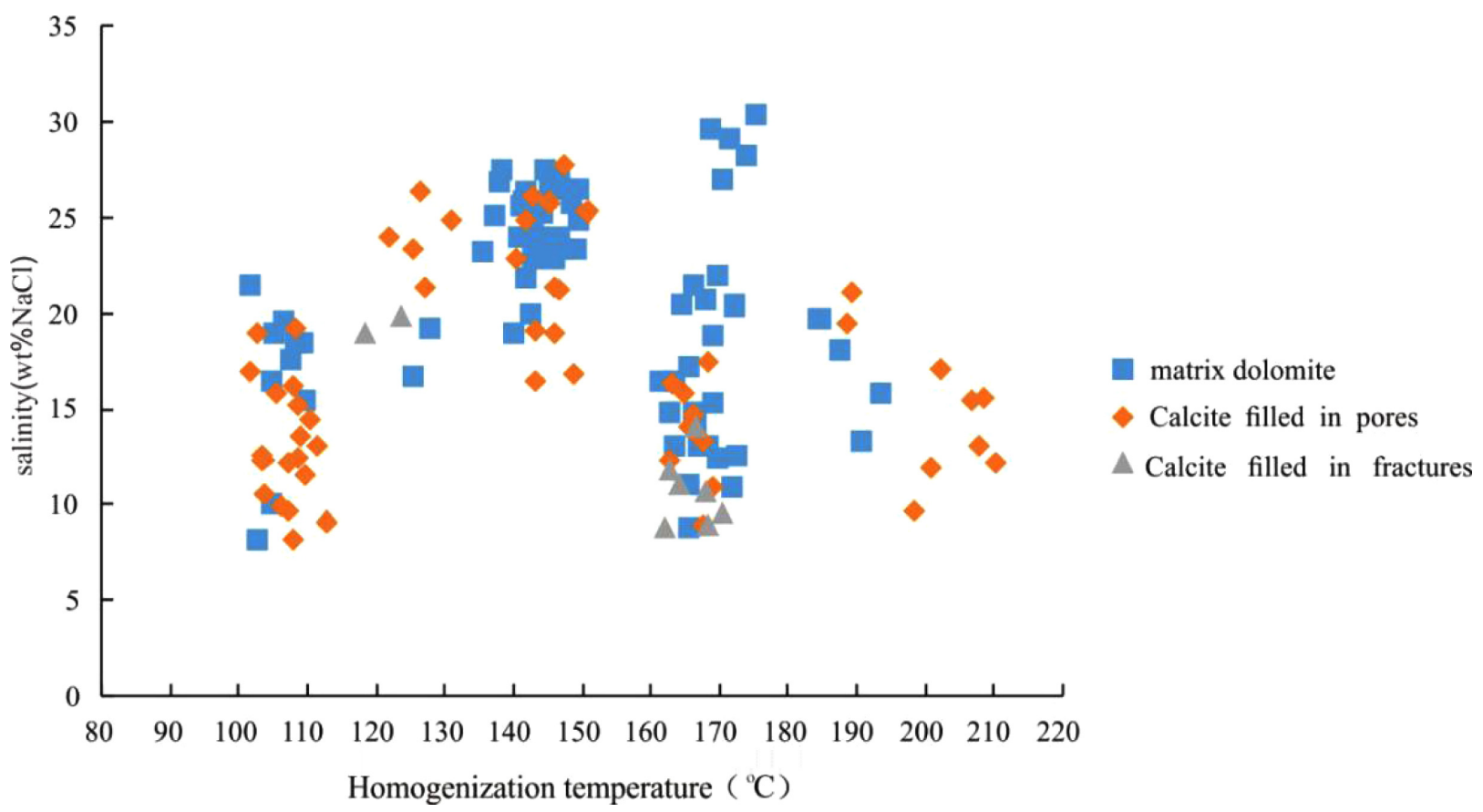

Figure 11. Salinity and homogeneity temperature cross-plot of the southwest Tarim Basin.
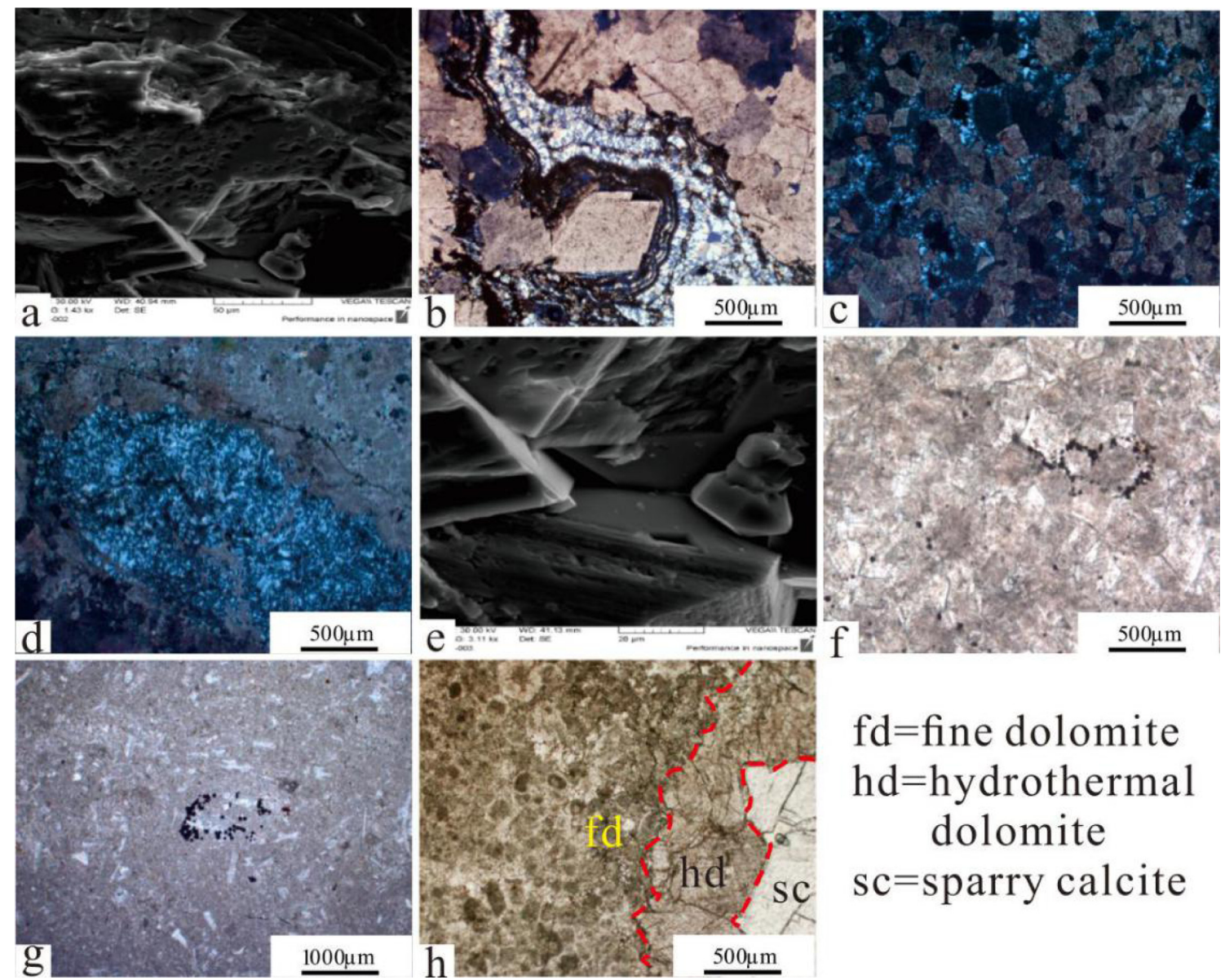

$\mathrm{fd}=$ fine dolomite hd=hydrothermal dolomite $\mathrm{sc}=$ sparry calcite

Figure 12. Hydrothermal characteristics of the Yubei area (a: Yubei 7 well, Penglaiba Formation, 6230.95 m, sandal dolomite with monocrystalline quartz; b: Yubei 5 well, Penglaiba Formation, $6739.1 \mathrm{~m}$, multi-stage flintstone with dolomite; : Yubei 1-2x well, Yingshan Formation, 5134.58 m, silicide-filled original pores; d: Yubei 3 well, Yingshan Formation, silicide-filled dissolved pores; e: Yubei 7 well, Penglaiba Formation, 6230.95 m, monocrystalline quartz; $f$ : Yubei 5 well, Penglaiba Formation, pyrite developed around dolomite crystals; g: Yubei 4 well, Yingshan Formation, 5607.4 m, cluster pyrite; h: Yubei 9 well, Penglaiba Formation, 6881.67 m, generational cementation). 


\section{Hydrothermal Minerals}

In the study area, high angle fractures, microfractures, karst seams, and pores are widely distributed, and are heavily filled with hydrothermal minerals including saddle dolomite, quartz, and pyrite (Fig. 12).

Saddle dolomites are typical minerals produced by deep hydrothermal solutions accompanied by the decomposition of organic matter in a deep burial environment with high temperatures (Radke and Mathis, 1980; Ahr, 2008; Zheng et al., 2009; Cuia et al., 2011). Saddle dolomites can be observed in both the Yubei 5 and Yubei 7 wells (Fig. 12a). In the Yubei 7 well, grain size of the saddle dolomite was mainly fine to medium and the cathodoluminescencec (CL) character was jacinth (Niu et al., 2017). In addition to saddle dolomite, flint was alos observed in the Yubei 7 well, as well as multi-stage flintstone which filled in dissolution pores (Fig. 12b).

During early diagenesis, silica from Si-rich diagenetic fluid precipitated and filled in primary pores. This silica was then preserved in subsequent diagenesis (Fig. 12c). In later diagenesis prior to the accumulation of petroleum, a fracture system developed and silica-rich diagenetic fluid migrated smoothly, with silicide precipitating and decreasing the porosity (Fig. 12d). Quartz exhibiting a typical hexagonal biconical shape was observed under a SEM, filling the area between matrix and saddle dolomite (Fig. 12e), suggesting that silicon formed after dolomitization and the hydrothermal process.

Pyrite can also be observed in the dolomite formation, which formed around coarse dolomite grains (Fig. 12f), indicating that it developed after the coarse dolomite. In the Yubei 9 well, at a depth of $6881.67 \mathrm{~m}$ in the Penglaiba Formation, generational cementation of sparry calcite-fine grain dolomite-saddle dolomite can be seen (Fig. 12h). Quartz associated with dolomite also exists in some of these dissolved pores and also in the Yubei 4 and Yubei 5 wells. These hydrothermal minerals all indicate that the hydrothermal process took place in the study area.
Table 8. Sr isotope characteristics of Yube 3 well

\begin{tabular}{|c|c|c|c|}
\hline Well & Depth $(\mathrm{m})$ & Lithology & ${ }^{87} \mathrm{Sr}{ }^{86} \mathrm{Sr}$ \\
\hline Yubei 3 & 5354 & siliceous dolomite & 0.70905 \\
\hline Yubei 3 & 5354.5 & siliceous dolomite & 0.70924 \\
\hline Yubei 3 & 5364.5 & siliceous dolomite & 0.70926 \\
\hline Yubei 3 & 5374 & siliceous dolomite & 0.7093 \\
\hline Yubei 3 & 5364 & siliceous dolomite & 0.7095 \\
\hline Yubei 3 & 5444 & silt-fine dolomite & 0.70875 \\
\hline Yubei 3 & 5444.5 & silt-fine dolomite & 0.70878 \\
\hline Yubei 3 & 5454 & silt-fine dolomite & 0.70884 \\
\hline Yubei 3 & 5454.4 & silt-fine dolomite & 0.70885 \\
\hline Yubei 3 & 5454.2 & silt-fine dolomite & 0.70887 \\
\hline Yubei 3 & 5454.3 & silt-fine dolomite & 0.7088 \\
\hline Yubei 3 & 5444 & silt-fine dolomite & 0.70886 \\
\hline Yubei 3 & 5494 & silt-fine dolomite & 0.7087 \\
\hline Yubei 3 & 5484 & silt-fine dolomite & 0.70882 \\
\hline Yubei 3 & 5484.5 & silt-fine dolomite & 0.70885 \\
\hline
\end{tabular}

\section{Isotope Characteristics}

Taking Yubei 3 well as an example, silicon developed around $5364 \mathrm{~m}$. For selected samples from the Yubei 3 well (Table 7 and 8 ), $\delta^{13} \mathrm{C}$ values of siliceous dolomite ranged from $-2.5 \%$ to $-0.1 \%$, with a mean value of $-1.01 \%$. $\delta^{18} \mathrm{O}$ values varied from $-11.3 \%$ to $-4.2 \%$, with a mean value of $-6.71 \%$. $\delta^{18} \mathrm{O}$ values of carbonate rocks in the siliceous-developed section were noticeably more negative, probably reflecting hydrothermal activities. The values of ${ }^{87} \mathrm{Sr} /{ }^{86} \mathrm{Sr}$ at $5354 \mathrm{~m}, 5354.5 \mathrm{~m}, 5364 \mathrm{~m}$, $5364.5 \mathrm{~m}$, and $5374 \mathrm{~m}$ were distinctly greater than the values between $5444 \mathrm{~m}$ and $5494 \mathrm{~m}$ (Fig. 13). This can be explained by the influence

Table 7. C and $O$ isotope characteristics of Yube 3 well

\begin{tabular}{|c|c|c|c|c|}
\hline Well & Depth $(\mathrm{m})$ & Lithology & $\delta^{18} \mathrm{O}_{\mathrm{VPDB}}(\%)$ & -7 \\
\hline Yubei 3 & 5258.75 & siliceous dolomite & -7.5 & -0.8 \\
\hline Yubei 3 & 5358.17 & siliceous dolomite & -8.4 & -0.4 \\
\hline Yubei 3 & 5360.26 & siliceous dolomite & -9.6 & -0.1 \\
\hline Yubei 3 & 5363.39 & siliceous dolomite & -8.3 & -0.6 \\
\hline Yubei 3 & 5366.26 & siliceous dolomite & -8.8 & -0.8 \\
\hline Yubei 3 & 5370.02 & siliceous dolomite & -8.4 & -0.9 \\
\hline Yubei 3 & 5444.25 & silt-fine dolomite & -5.4 & -1.2 \\
\hline Yubei 3 & 5445.72 & silt-fine dolomite & -6.1 & -0.6 \\
\hline Yubei 3 & 5449.62 & silt-fine dolomite & -5.2 & -0.2 \\
\hline Yubei 3 & 5450.86 & silt-fine dolomite & -4.2 & -0.8 \\
\hline Yubei 3 & 5452.53 & silt-fine dolomite & -4.9 & -1.60 \\
\hline Yubei 3 & 5494.23 & silt-fine dolomite & -5.3 & -1.70 \\
\hline Yubei 3 & 5496.20 & silt-fine dolomite & -5.4 & -1.8 \\
\hline Yubei 3 & 5497.84 & silt-fine dolomite & -4.6 & \\
\hline
\end{tabular}




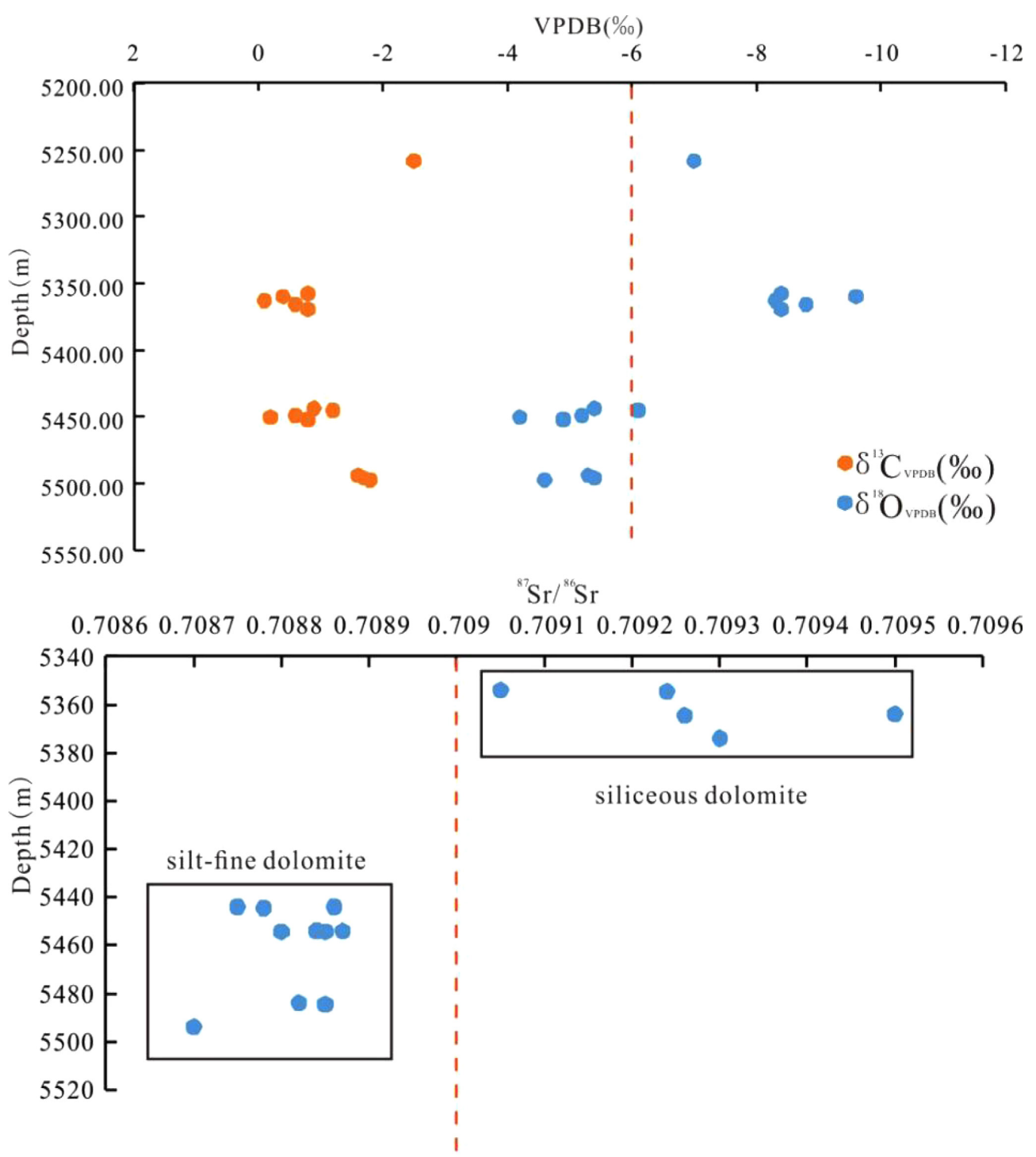

Figure 13. $C, O$, and Sr isotope characteristics of dolomite in the Penglaiba Formation from the Yubei 3 well.

of hydrothermal fluids that migrated upward. ${ }^{87} \mathrm{Sr}$-rich fluid upwelling can lead to increased values of ${ }^{87} \mathrm{Sr} /{ }^{86} \mathrm{Sr}$.

\section{High-Temperature Aqueous Inclusions}

In addition to minerals, the evidence for hydrothermal activities from geochemical data also includes temperature values from the inclusions. Temperatures from a portion of the inclusions exceeded $200{ }^{\circ} \mathrm{C}$. Based on Fig. 14, the maximum burial temperature of the Penglaiba Formation was between $150-160{ }^{\circ} \mathrm{C}$ (Tan et al., 2014). Comparing the homogeneous temperature of inclusions to the maximum burial temperature of the Penglaiba Formation, if the inclusion temperature was less than or equal to $160^{\circ} \mathrm{C}$, it would not indicate hydrothermal activity, but if it reached $200{ }^{\circ} \mathrm{C}$, there would be no doubt that the formation experienced hydrothermal activity.

In the southwest Tarim Basin, there is no typical hydrothermal dolomite reservoir such as the one found in the Devonian of the Canada Basin, indicating that typical hydrothermal dolomite is less common in the study area. Hydrothermal dolomite mainly developed in or around fractures, pores, and caves. Hydrothermal fluid affects formation in different ways, dissolving strata and forming secondary pores, recrystallized dolomite, saddle dolomite, and quartz.

Overall, quartz, pyrite, and saddle dolomite were observed in the study cores and thin sections. The maximum temperature of the formations was $160^{\circ} \mathrm{C}$, but some homogenization temperatures of the aqueous inclusions exceeded $200{ }^{\circ} \mathrm{C} . \delta^{18} \mathrm{O}$ values were relatively more negative than those found in normal dolomite, and the ${ }^{87} \mathrm{Sr} r{ }^{86} \mathrm{Sr}$ values were relatively high. These characteristics all suggest hydrothermal activity.

\section{Genetic Model of Dolomite}

The petrology characteristics of Ordovician dolomite in the study area are dominated by silt-fine dolomite, with middle-coarse dolomite distributed along stylolites and fractures. $\mathrm{C}, \mathrm{O}$, and $\mathrm{Sr}$ isotopes suggest that the silt-fine dolomite formed during the contemporaneouspenecontemporaneous period, and made up the majority of the dolomite in the study area. Previous research ha found that minerals asso- 


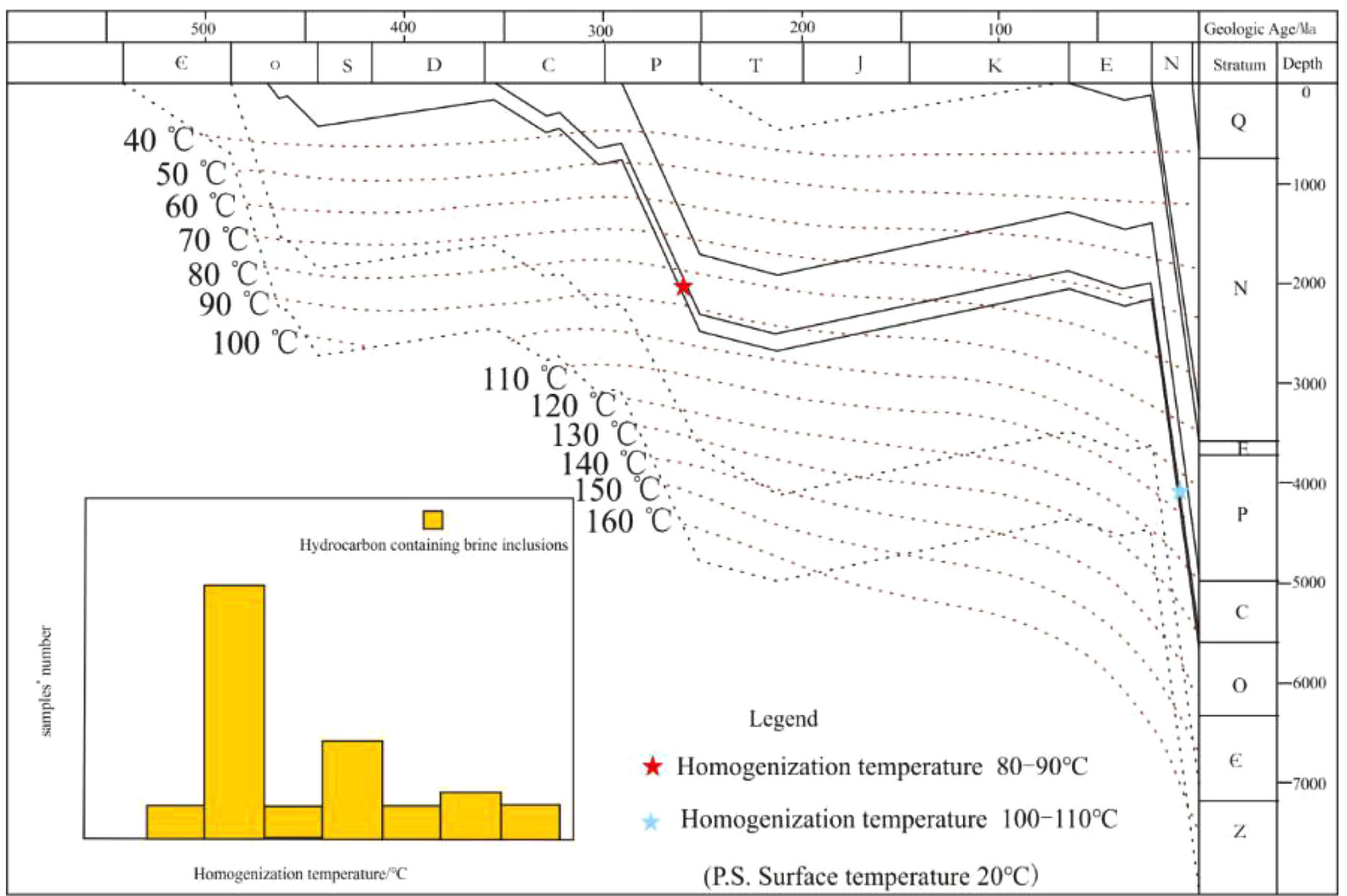

Figure 14. Reservoir burial-thermal history and hydrocarbon accumulation period of the southwest Tarim Basin(according to Tan et al., 2014).

ciated with intense evaporation exist in the Tazhong region, but in the current study area those sorts of minerals were not found, thus indicating that during geological history the Yubei area may not have been affected by such an intense evaporating environment. This may also be the reason that burial dolomite is not continuous in the study area. In addition, although some researchers have pointed out that dolomite southwest of the Tarim Basin may have been affected by hydrothermal fluid, these scientists did not provide enough corroborating evidence tosupport their hypothesis. In this study, evidence for hydrothermal activities has been provided in the form of petrology, as well as geochemical and fluid inclusion characteristics, especially the homogenization temperatures of inclusions, which directly proved the existence of hydrothermal activities. Hydrothermal dolomitization occurred in a deep burial environment during the middle to late Caledonian and early Hercynian periods. A fracture system developed in the stratum and hydrothermal fluid migrated along the fracture system up to the Ordovician.

\section{Conclusions}

Lower Ordovician dolomite in the southwest Tarim Basin formed primarily during the contemporaneous-penecontemporaneous period. The lithology of this type of dolomite is mainly silt-fine. Burial dolomite is large and consists of euhedral to subhedral crystalline forms was original from silt-fine dolomite. During the deep burial period, $\mathrm{Mg}$-rich fluid transported along stylolites and fractures provided the dolomitization fluid and led to burial dolomitization.
Hydrothermal dolomitization was also found to exist in the study area. The transport of dolomitization fluid through Precambrian clastic rock crossed the Cambrian and interacted with dolomite in the Ordovician, resulting in higher ${ }^{87} \mathrm{Sr} /{ }^{86} \mathrm{Sr}$ values.

\section{Acknowledgments}

This work was supported by the Research Foundation of China University of Petroleum-Beijing At Karamay [RCYJ2017B-01-002] and the Major Program of National Natural Science Foundation of ChinaReservoir geology and evaluation in new field [2011ZX05009-002-203].

\section{Reference}

Adams, J.E., and Rhodes, M.L., 1960, Dolomitization by seepage refluxion. American Association of Petroleum Geologists Bulletin, v. 44, pp. 1912-1920.

Ahr, W.M., 2008, Geology of carbonate reservoirs. New Jersey: John Wiley \& Sons, Inc, Hoboken, 2117p.

Allen, J.R., and Wiggings, W.D., 1993, Geochemical techniques for evaluating origin and distribution. In: Mazzullo, S.J., Chilingarian, G.V., Dolomite Reservoirs. Tulsa. American Association of Petroleum Geologists, v. 14, pp. 262-263.

Cai, C., Li, K., Li, H., and Zhang, B., 2008, Evidence for cross formational hot brine flow from integrated $87 \mathrm{sr} / 86 \mathrm{sr}$, ree and fluid inclusions of the ordovician veins in central tarim, china. Applied Geochemistry, v. 23, pp. 2226-2235.

Coleman, M.L., Walsh, J.N., and Benmore, R.A., 1989, Determination of 
both chemical and stable isotope composition in milligram-size carbonate samples. Sedimentary Geology, v. 65, pp. 233-238.

Cuia, R.D., Riva, A., and Scifoni, A., 2011, Dolomite characteristics and diagenetic model of the Calcari Grigi Group (Asiago Plateau, Southern Alps-Italy): an example of multiphase dolomitization. Sedimentology, v. 58, pp. 1347-1369.

Ding, W.L., Qi, L.X., Yun, L., Yu, T.X., Wu, L.M., Cao, Z.C., and You, S.G., 2012, The tectonic evolution and its controlling effects on the development of Ordovician reservoir in Bachu, Markit, Tarim Basin. Acta Petrologica Sinica, v. 28, pp. 2542-2556.

Du, Y.M., Yu, T.X., Hao, J.L., and Qiu, H.B., 2013, Fracture characteristics and control action on hydrocarbon accumulation in Yubei Area of Tarim Basin. Fault-Block Oil and Gas Field, v. 20, pp. 170-174.

Davies, G.R. and Smith, L.B., 2011, Structurally controlled hydrothermal dolomite reservoir facies: an overview: reply. AAPG Bulletin, v. 90, pp. 1641-1690.

Frimmel, H.E., 2009, Trace element distribution in Neoproterozoic carbonates as palaeoenvironmental indicator. Chemical Geoglogy, v. 258, pp. 338-353.

Graham, R.D., and Langhorne, B.S., 2006, Structurally controlled hydrothermal dolomite reservoir facies: An overview. AAPG Bulletin, v. 90, pp. 1641-1690.

Gu, J.Y., 2000, Characteristics and origin analysis of dolomite in lower Ordovician of Tarim Basin. Xinjiang Petroleum Geology, v. 21, pp. $120-122$.

Hanshaw, B.B., Back, W., and Deike, R.G., 1971, A geochemical hypothesis for dolomitization by ground water. Economic Geology, v. 66, pp. 710-724.

He, D.F., Jia, C.Z., Li, D.S., Zhang, C.J., Meng, Q.R. and Shi, X., 2005, Formation and evolution of polycyclic superimposed Tarim Basin. Oil \& Gas Geology, v. 26, pp. 64-77.

Heydari, E. 1997, Hydrotectonic models of burial diagenesis in platform carbonates based on formation water geochemistry in north American sedimentary basins. Special Publications, v. 57, pp. 53-79.

Hu, W.X., Chen, Q., Wang, X.L., and Cao, J., 2010, REE models for the discrimination of fluids in the Formation and evolution of dolomite reservoirs. Oil \& Gas Geology, v. 31, pp. 810-818.

Hu, M.Y., Hu, Z.G., Li, S.T. and Wang Y.Q., 2011, Geochemical characteristics and genetic mechanism of the Ordovician dolostone in the Tazhong Area, Tarim Basin. Acta Geologica Sinica, v. 85, pp. 2060-2069.

Huang, S.J., Shi, H., Mao, X.D., Zhang M., Shen, L.C., and Wu, W.H., 2002, Strontium isotope evolution curve and global comparison of Cambrian in Xiushan, Chongqing. Geological Review, v. 48, pp. 509-516.

Huang, W.H., Yang, M., Yu, B.S., Fan, T.L., Chu, G.Z., 2006, Strontium isotope composition and its characteristics analysis of Cambrian-Ordovician carbonate in Tazhong District, Tarim Basin. Earth Science- Journal of China University of Geoscience, v. 31, pp. 839-845.

Huang, Q.Y., Zhang, S.N., Ye, N., and Li, Y.T., 2014, Petrologic,geochemical characteristics and origin of the Lower Ordovician dolomite in Yubei area. Oil \& Gas Geology, v. 35, pp. 391-400.

Ihsan, A., 2003, Origin and characterization of hydrothermal dolomite in the Western Canada sedimentary basin. Journal of Geochemical Exploration, v. 78, pp. 9-15.

Jia, C.Z., 1995, Basin tectonic evolution and regional tectonic geology. Petroleum industry press, Beijing, 562p.

Jiang, M.S., Zhu, J.Q., Chen, D.Z., Zhang, R.Y. and Qiao, G.S., 2002, Carbon and strontium isotope characteristics of ordovician carbonate in Tarim basin and its response to sea level change. China Science (D: Geoscience), v. 32, pp. 36-42.

Jin, Z., Zhu, D.Y., Hu, W.X., Zhang, X.F., Wang, Y. and Yan, X.F., 2006, Geological and geochemical signatures of hydrothermal activity and their influence on carbonate reservoir beds in the Tarim Basin. Acta Geologica Sinica, v. 80, pp. 245-253.

Kang, Y.Z., 2008, Ancient karst reservoir characteristics and hydrocarbon distribution in Paleozoic carbonate rocks in China. Marine Origin Petro- leum Geology, v. 28, pp. 1-12.

Kirmaci, M.Z., and Kemal, A., 2005, Origin of dolomite in the late Cretaceous-Paleocene limestone turbidites, eastern Pontides, Turkey. Sedimentary Geology, v. 181, pp. 39-57.

Land, L.S., 1985, The origin of massive dolomite. Journal of Geological Education, v. 33, pp. 112-125.

Li, Z., Goldstein, R.H., Franseen, E.K., 2013, Ascending freshwater-mesohaline mixing: A new scenario for dolomitization. Journal of Sedimentary Research, v. 83, pp. 277-283.

Liu, H.N., Huang, S.J., Hu, Z.W., Wu, M., and Wang, Q.D., 2007, Advances of strontium isotope in sedimentology. Lithologic Reservoirs, v. 19, pp. 59-65.

Liu, Z.B., Gao, S.L., Liu, S.L., Wu, S.Q., and Ma, Y.C., 2015, Ordovician carbonate sedimentary characteristics and models of Bachu-Maigaiti region in Tarim Basin. Journal of Central South University (Science and Technology), v. 11, pp. 4165-4173.

Meyers, W.J., Lu, F.H., and Zachariah, J.K., 1997, Dolomitization by mixed evaporative brines and freshwater, upper Miocene carbonates, Nijar, Spain. Journal of Sedimentary Research, v. 67, pp. 898-912.

Niu, J., Huang, W.H., and Ding, W.L., 2017, Carbon and oxygen isotope characteristics and its significance of Ordovician carbonates in Yubei Area of Maigaiti Slope. Journal of Jilin University (Earth Science Edition), v. 47, pp. 61-73.

Niu, J., Huang W. H., and Liang F., 2018, Paleoenvironment in an Ordovician carbonate reservoir in southwestern of Tarim Basin, NW China: Evidence from stable isotopes. Energy Sources Part A, online. dio: 10.1080/15567036.2018.1549129.

Peng, S.P., He, H., Shao, L.Y., Shi, Z.P. and Gao, Y.F., 2002, Carbon isotopic compositions of the Cambrian-Ordovician carbonates in Tarim Basin. Journal of China University of Mining \& Technology, v. 31, pp. 353-357.

Qiang, Z.T., 1998, Carbonate reservoir geology, China University of Petroleum press, Dongying. 470p.

Radke, B.M., Mathis, R.L., 1980, On the formation and occurrence of saddle dolomite. Journal of Sedimentary Petrology, v. 50, pp. 1149-1168.

Si, S.H., Chen, H.H., Tan, X.F., Li, C.Q., Wu, Y., and Li,N., 2013, Hydrocarbon accumulation period and its carrier systems in Ordovician reservoir of Yubei Area, Markit Slope, Tarim Basin. Editorial Committee of Earth Science-Journal of China University of Geosciences, v. 38, pp. 1271-1280.

Shields, G.A., Carden, G., and Veizer, J., 2003, Sr, C, and O isotope geochemistry of Ordovician brachiopods: A major isotopic event around the Middle-Late Ordovician transition. Geochimica et Cosmochimica ACTA, v. 67, pp. 2005-2025.

Sugitani, K., 1992, Geochemical characteristics of Archean cherts and other sedimentary rocks in the Pilbara Block, western Australia: Evidence for Archean seawater enriched in hydrothermally-derived iron and silica. Precambrian Research, v. 57, pp. 21-47.

Sverjensky, D.A., 1984, Europium redox equilibria in aqueous solution. Earth \& Planetary Science Letters, v. 67, pp. 70-78.

Tan, G.H., Qiu, H.B., Yu, T.X., Liu, S.J., and Hao, J.L., 2014, Characteristics and main controlling factors of hydrocarbon accumulation in Ordovician Yingshan Formation in Yubei area,Tarim Basin. Oil \& Gas Geology, v. 35, pp. 26-32.

Tang, L.J., Jin, W.Z., He, C.B., Cui, M., Ning, F., and Wan, G.M., 2009, Key tectonic changes and staging differential structural deformation in superimposed basins. Xinjiang Petroleum Geology, v. 30, pp. 163-167.

Tucker, M.E., Wright, V.P., and Dickson, J.A.D., 1990, Carbonate sedimeitology. Oxford: Blackwell Science, 536p.

Veizer, J., Ala, D., and Azmy K., $1999,{ }^{87} \mathrm{Sr} /{ }^{86} \mathrm{Sr}, \delta^{13} \mathrm{C}$ and $\delta^{18} \mathrm{O}$ evolution of Phanerozoic seawater. Chemical Geology, v. 161, pp. 59-88.

Wu, S.Q., Zhu, J.Q., Wang, G.X., Hu, W.X., Zhang, J.T. and Wang, X.L., 2008, Types and origin of Cambrian-Ordovician dolomites in Tarim basin. Acta Petrologica Sinica, v. 24, pp. 1390-1400.

Wu, X.S., Wei, J.X., Chang, J.B., and Han, J.F., 2009, Difficulty and countermeasures in carbonate paleokarst reservoir prediction. Journal of China 
University of Petroleum (Edition of Natural Science), v. 33, pp. 16-21.

Yang, W., Wang, Q.H., and Liu, X.Z., 2000, Dolomite origin of lower Ordovician in Hetian river gas field, Tarim Basin. Acta Sedimentological Sinica, v. 18, pp. 544-548.

Yun, L., and Zhai, Y.X., 2008, Discussion on characteristics of the Cambrian reservoirs and hydrocarbon accumulation in Well Tashen-1, Tarim Basin. Oil \& Gas Geology, v. 29, pp. 726-732.

Zhao, C., Yu, B., Zhang, C., Shen, Y., and Qi, X., 2012, A discussion on the formation mechanism of dolomite associated with hydrothermal solution in Tazhong area. Acta Petrologica et Mineralogica, v. 31, pp. 165172.

Zhang, D.M., Bao, Z.D., Pan, W. Q., Hao, Y. and Chen, M., 2013, Type and origin of the Lower Paleozoic dolostones in Tarim Basin. Journal of Palaeogeography, v. 15, pp. 693-706.

Zhang, J., and Luo, P., 2010, Genesis of Ordovician matrix-porosity dolomite reservoir in the Tarim Basin. Petroleum Geology and Experiment, v. 32 , pp. $470-474$.

Zhang, X.G., 2012, Study on Seismic response characteristics of carbonate reservoir in Yubei area. Geophys. Prosp. Petrol. v. 51, pp. 493-501.

Zhang, X.L., 1985, Relationship between oxygen and carbon stable isotopes in carbonate rocks and paleosalinity and paleotemperature. Acta Sedimentologica Sinica, v. 4, pp.17-30.

Zhang, Z.P., Liu, S.L., Yang, Z.Y., and Li, J.J., 2011, Tectonic evolution and its petroleum geological significances of the Maigaiti Slop, Tarim Basin. Oil \& Gas Geology, v. 32, pp. 909-919.

Zheng, H.R., Liu, C.Y., Wu, M.B., and Wang, Y., 2009, Burial dissolution of Ordovician granule limestone in Tarim Basin. Acta Petrolei Sinic, v. 30, pp. 9-15.

Zheng, J.F., Shen, A.J., Liu, Y.F., and Chen, Y.Q., 2012, Multi-parameter comprehensive identification of the genesis of lower Paleozoic dolomite in Tarim Basin, China. Acta Petrolei Sinica, v. 33, pp. 145-153.

Zheng, R.C. and Chen, D.H., 1997, Geochemical, characteristics of trace and rare earth elements of paleokarst reservoirs in Huanglong Formation of eastern Sichuan. Journal of Chengdu University of Technology, v. 24 , pp. $5-11$.

Zheng, R.C., Shi, J.N., Luo, A.J., Li, S. and Li, G.L., 2008, Comparative study on ceochemical behaviors of dolomite reservoirs in northeast Sichuan basin. Natural Gas Industry, v. 28, pp. 16-21.

Zhou, X.Y., 2006, Ordovician carbonate hydrocarbon accumulation characteristics and exploration direction in Tazhong I tectonic belt. International symposium on oil and gas accumulation mechanism and resource evaluation, p. 215-224.

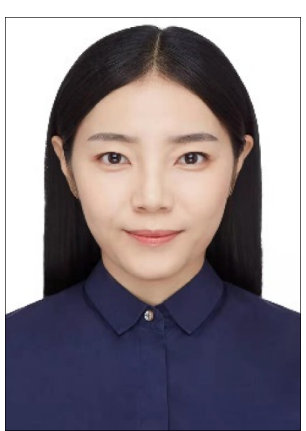

Jun Niu is a lecturer at China University of Petroleum (Beijing) at Karamay campus in China. Her research interests are carbonate diagenesis, petroleum geology and geochemistry. She has published several papers on Ordovician stratigraphy of Tarim Basin. And focus on the characteristic of dolomite.

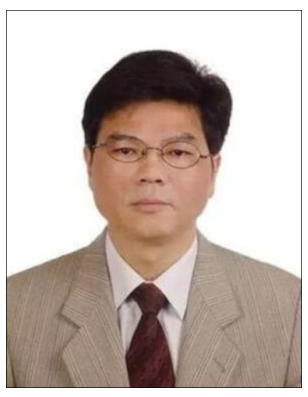

Wenhui Huang is a Full Professor at China University of Geoscience (Beijing) in China. His research interests are carbonate sedimentation, carbonate diagenesis, paleoenvironment and geochemistry. He has published papers on Ordovician, Carboniferous and Permian stratigraphy, and $\mathrm{C}, \mathrm{O}, \mathrm{Sr}$ isotopic dating.

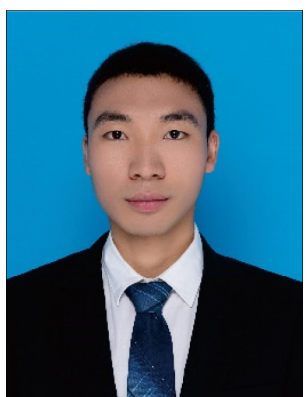

Fei Liang is a Ph.D student in T.U. Darmstadt. After he completing a master in sedimentary geology at China University of Geoscience (Beijing), now, he is continuing his $\mathrm{Ph}$.D research at T.U. Darmstadt. His research focus on mineralogical, geochemical and petrophysical characterisation of the post-Variscan unconformity in Central Europe. 